\title{
Vertical profiles of aerosol and black carbon in the Arctic: a seasonal phenomenology along 2 years (2011-2012) of field campaigns
}

\author{
Luca Ferrero $^{1}$, David Cappelletti ${ }^{2,3}$, Maurizio Busetto ${ }^{3}$, Mauro Mazzola ${ }^{3}$, Angelo Lupi ${ }^{3}$, Christian Lanconelli $^{4}$, \\ Silvia Becagli ${ }^{5}$, Rita Traversi ${ }^{5}$, Laura Caiazzo ${ }^{5}$, Fabio Giardi ${ }^{5}$, Beatrice Moroni $^{2}$, Stefano Crocchianti ${ }^{2}$, \\ Martin Fierz $^{6}$, Griša Močnik ${ }^{7,8}$, Giorgia Sangiorgi ${ }^{1}$, Maria G. Perrone ${ }^{1}$, Marion Maturilli ${ }^{9}$, Vito Vitale ${ }^{3}$, \\ Roberto Udisti ${ }^{5}$, and Ezio Bolzacchini ${ }^{1}$ \\ ${ }^{1}$ Department of Earth and Environmental Sciences, University of Milano-Bicocca, Piazza della Scienza 1, \\ 20126 Milan, Italy \\ ${ }^{2}$ Department of Chemistry, Biology and Biotechnology, University of Perugia, 06123 Perugia, Italy \\ ${ }^{3}$ Institute of Atmospheric Sciences and Climate, CNR-ISAC, via Gobetti 101, 40129 Bologna, Italy \\ ${ }^{4}$ European Commission, Joint Research Centre (JRC), Institute for Environment \& Sustainability, \\ via E. Fermi, 21027 Ispra, Italy \\ ${ }^{5}$ University of Florence, Via della Lastruccia 3, 50019 Florence, Italy \\ ${ }^{6}$ University of Applied Sciences and Arts Northwestern Switzerland, Windisch, Switzerland \\ ${ }^{7}$ Aerosol d.o.o., Kamniska 41, 1000 Ljubljana, Slovenia \\ ${ }^{8}$ Condensed Matter Physics Department, Jozef Stefan Institute, Jamova 39, 1000 Ljubljana, Slovenia \\ ${ }^{9}$ Alfred Wegener Institute, Helmholtz Centre for Polar and Marine Research, Telegraphenberg 43A, \\ 14473 Potsdam, Germany
}

Correspondence to: Luca Ferrero (luca.ferrero@unimib.it)

Received: 26 February 2016 - Published in Atmos. Chem. Phys. Discuss.: 13 April 2016

Revised: 14 August 2016 - Accepted: 13 September 2016 - Published: 11 October 2016

\begin{abstract}
We present results from a systematic study of vertical profiles of aerosol number size distribution and black carbon (BC) concentrations conducted in the Arctic, over $\mathrm{Ny}$-Ålesund (Svalbard). The campaign lasted 2 years (20112012) and resulted in 200 vertical profiles measured by means of a tethered balloon (up to $1200 \mathrm{~m}$ a.g.l.) during the spring and summer seasons. In addition, chemical analysis of filter samples, aerosol size distribution and a full set of meteorological parameters were determined at ground. The collected experimental data allowed a classification of the vertical profiles into different typologies, which allowed us to describe the seasonal phenomenology of vertical aerosol properties in the Arctic.

During spring, four main types of profiles were found and their behavior was related to the main aerosol and atmospheric dynamics occurring at the measuring site. Background conditions generated homogenous profiles. Transport events caused an increase of aerosol concentration with altitude. High Arctic haze pollution trapped below thermal in-
\end{abstract}

versions promoted a decrease of aerosol concentration with altitude. Finally, ground-based plumes of locally formed secondary aerosol determined profiles with decreasing aerosol concentration located at different altitude as a function of size.

During the summer season, the impact from shipping caused aerosol and BC pollution plumes to be constrained close to the ground, indicating that increasing shipping emissions in the Arctic could bring anthropogenic aerosol and BC in the Arctic summer, affecting the climate.

\section{Introduction}

The Arctic is subject to an amplification of the global warming, as the observed temperature increase has been almost twice the global average (IPCC, 2013; Serreze and Barry, 2011; Shindell and Faluvegi, 2009). This resulted in the first complete opening of the Northwest Passage in 2007 
(Serreze et al., 2007) together with a greening of the coastal tundra (Bhatt et al., 2010) and altered wind patterns (Overland and Wang, 2010). The Arctic amplification is the result of complex global feedbacks (acting at different spatial and temporal scales): the impact of sea ice changes on the heat fluxes between the ocean and the atmosphere (Screen and Simmonds, 2010a, b), the effect of changes in the cloud cover and water vapor on the longwave radiation fluxes (Francis and Hunter, 2006), the changes in atmospheric and oceanic heat transports (Yang et al., 2010), the black carbon (BC) deposition on the snow (Hansen and Nazarenko, 2004) and the changes in the atmospheric BC and aerosol concentrations themselves (Flanner, 2013; Serreze and Barry, 2011; Shindell and Faluvegi, 2009). Many of these processes depend on aerosol absorption and scattering of the solar radiation (direct effect). Additionally, indirect effects play an important role as the aerosols seed and modify the cloud properties. Lastly, light absorption by BC can alter the atmospheric thermal structure within, below or above clouds, consequently affecting cloud distributions (IPCC, 2013; Bond et al., 2013; Ramanathan and Feng, 2009; Koren et al., 2004, 2008; Kaufman et al., 2002). Shindell and Faluvegi (2009) estimated that globally the decreasing concentrations of sulfate aerosols and the increasing concentrations of BC contributed (during 1976-2007) $1.09 \pm 0.81^{\circ} \mathrm{C}$ to the Arctic surface temperature increase of $1.48 \pm 0.28^{\circ} \mathrm{C}$.

Aerosol particles are short-lived pollutants $(\sim 1$ to several weeks of residence time) and act as short-lived climate forcers; thus, their effect could be employed in short-term climate strategies (Ødemark et al., 2012; Shindell et al., 2012; Jacobson, 2010; Quinn et al., 2008). To adopt the right mitigation strategies, key scientific issues in the study of Arctic aerosols have to be solved. They include the identification of the relative importance of long-range advection with respect to local emissions (Flanner, 2013; Sand et al., 2013; Shindell and Faluvegi, 2009). Most importantly, the seasonal characterization of the aerosol vertical structure, a very poorly determined piece of information, is required.

Indeed, the aerosol properties (size distribution, chemical composition, optical properties) in the Arctic exhibit a pronounced seasonal variation due to an interplay of dominating sources (outside or inside the Arctic region) with meteorological conditions that allow or inhibit the transport from source regions (Quinn et al., 2008; Eckhardt et al., 2003). The spring period is characterized by the presence of the Arctic haze dominated by the accumulation-mode aerosol (enriched in BC). During the Arctic haze, an inflow of pollution (aerosol and gases) from northern midlatitudes (during winter-spring) results in a reduction in visibility (Jacob et al., 2010; Stohl et al., 2006; Radke et al., 1984; Barrie and Hoff, 1985; Brock et al., 1989; Shaw, 1995). The Arctic haze occurs under meteorological conditions with stable stratifications and the frequent and persistent occurrences of surface-based inversions. According to Stohl et al. (2006), within these conditions, the air pollution can be transported into the Arctic at low level (followed by ascent in the Arctic or low level alone) or with an uplift outside the Arctic, followed by descent in the Arctic itself. The summer period is dominated by fresh Aitken particles, locally formed, with a negligible BC content (Tunved et al., 2013; Spackman et al., 2010; Eleftheriadis et al., 2009; Ström et al., 2003, 2009; Udisti et al., 2013; Viola et al., 2013).

In addition to the aforementioned seasonality, the same type of aerosol can produce different climatic effects (warming or cooling) and local feedbacks (snow/ice albedo, clouds) depending on its vertical location (Flanner, 2013; Sand et al., 2013; Ban-Weiss et al., 2011; Shindell and Faluvegi, 2009). For example, it is well known that $\mathrm{BC}$ aerosol absorbs solar radiation and heat the surrounding air (Ferrero et al., 2011a, 2014; Samset et al., 2013, 2014; Ramana et al., 2007). The surface temperature response varies considerably with the altitude of the induced heating. BC may potentially warm the Arctic if it is located immediately above snow and ice while it has a cooling effect, if it is located in the free troposphere. In the latter case, BC may reduce the surface air temperature and promote the increase in the sea-ice fraction (Flanner, 2013; Brock et al., 2011; Seinfeld and Pandis, 2006; Hansen and Nazarenko, 2004). The latter phenomenon results from a combination of the weakening of the northward heat transport (due to a reduction in the meridional temperature gradient) and the increasing of atmospheric stability (caused by the contemporary dimming of the surface and heating aloft) which turns into a reduction of the downward sensible heat flux (Flanner, 2013; Sand et al., 2013; Shindell and Faluvegi, 2009).

In addition to the vertical distribution of $\mathrm{BC}$, that of the total aerosol particles is important: it can influence the indirect effect and the related feedbacks. Changes in the cloud cover (especially low-level Arctic stratus) increase the downward longwave flux to the surface as a function of the cloud base temperature and cloud phase (liquid, mixed or ice) (Serreze and Barry, 2011; Francis and Hunter, 2006). Low clouds mainly warm the surface in the Arctic (with the exception of a brief period in summer) (Vavrus et al., 2009; Intrieri et al., 2002) due to the stable stratified conditions that often prevail in the Arctic (Manabe and Wetherald, 1975). Because the highest number density of aerosol particles observed in the Arctic is due to a locally formed aerosol (mainly in summer as stated above) (Tunved et al., 2013; Engvall et al., 2008a; Ström et al., 2003) it is important to assess the vertical behavior of the aerosol concentration as a function of its size and the season. It is therefore necessary to measure the vertical profiles in the Arctic. For this purpose, several field campaigns have been performed in the Arctic in recent years with the aim to characterize aerosol properties along the vertical direction.

The ARCTAS mission (Jacob et al., 2010, and references therein) showed highly layered air pollution transport from North America and east Asia in the spring, characterized by anthropogenic aerosol below $2 \mathrm{~km}$ and by biomass burn- 
ing in the $2-4 \mathrm{~km}$ layer. The ARCPAC campaign (Brock et al., 2011) grouped the aerosol affecting the Arctic in spring in four categories: background troposphere (relatively diffuse, sulfate-rich aerosol); depleted aerosol within the surface inversion layer over sea ice; layers of organic-rich biomass burning aerosol (above the top of the inversion layer) (see also Warneke et al., 2010) and layers dominated by fossil fuel combustion. The ASTAR campaign (Engvall et al., 2008), focused on the spring to summer transition period in Svalbard, found Aitken and accumulation-mode particles more concentrated in the free troposphere compared to the boundary layer. Kupiszewski et al. (2013) reported new particle formation events in the near-surface layer (possibly related to biological processes) during the summer ASCOS campaign.

Considering the $\mathrm{BC}$, the springtime PAM-ARCMIP (Stone et al., 2010) and HIPPO (Schwarz et al., 2010) campaigns showed high $\mathrm{BC}$ concentrations close to the ground, below the thermal inversion, but also dense pollution and BC at high altitudes over the Arctic (Wofsy et al., 2011). Interestingly, the PAM-ARCMIP results show a decrease of BC compared to past measurements (i.e., AGASP; Hansen and Novakov, 1989). In addition, the HIPPO campaign revealed that in the lower troposphere the $\mathrm{BC}$ vertical gradient can change seasonally from positive to negative (Schwarz et al., 2013). In this respect, Spackman et al. (2010) and Koch et al. (2009) reported BC located mainly in the Arctic free troposphere with a positive gradient in the lower troposphere.

The aforementioned campaigns were conducted mainly using aircraft (or helicopters) that are limited to intensive observational periods (Kupiszewski et al., 2013; Bates et al., 2013; Spackman et al., 2010; Schwarz et al., 2010; Koch et al., 2009). Thus, aerosol vertical profiles in the Arctic appear scarce if compared with the number of available data collected at ground level (Samset et al., 2013; Koch et al., 2009). There is the need for regular vertical aerosol profiling campaigns to improve the description of a seasonally resolved aerosol and $\mathrm{BC}$ vertical behavior.

In addition to this, aerosol vertical distribution could be affected in the future by changes in the aerosol emissions within the Arctic itself. The increasing of shipping emission in the Arctic is a good example. Shipping emissions inject the $\mathrm{BC}$ directly into the Arctic planetary boundary layer (probably warming the surface and depositing on snow and ice). The importance of the increasing shipping emission in the Arctic has been recently underlined (Eckhardt et al., 2013; Corbett et al., 2010; Granier et al., 2006). Although the final impact is debated (Browse et al., 2013), the effective vertical distribution of these emissions has not yet been investigated. Thus, there is a clear need to also improve the knowledge about aerosol vertical profiles in the Arctic during week-long campaigns along years to find common rules of behavior.

The Arctic site of Ny-Ålesund (Svalbard Islands) is particularly suitable for such measurements, featuring long-term data series of ground-based aerosol properties, lidar profiles, radiometric and meteorological data (Maturilli and Kayser,
2016; Tunved et al., 2013; Di Liberto et al., 2012; Vihma et al., 2011; Hoffmann et al., 2009; Eleftheriadis et al., 2009; Stock et al., 2012; Ström et al., 2003, 2009). Longterm upper-air observations by daily radiosondes provided an overview of the atmospheric vertical structure above $\mathrm{Ny}-$ Ålesund, including the planetary boundary layer (PBL) altitude range (Maturilli and Kayser, 2016; Vihma et al., 2011). In this climatological approach, stable atmospheric conditions, radiative surface-based inversions were frequently found during polar night conditions, indicating stable atmospheric conditions with suppressed vertical exchange. Once the snowmelt leads to considerable sensible and latent heat fluxes at the surface, atmospheric stratification becomes neutral or instable, allowing convection and vertical mixing.

These observations point towards the need to understand how the aerosol is vertically layered as a function of the meteorological changes along seasons. Despite this, as stated above, aerosol and BC measurements along vertical profiles are reported to be sparse; even recent UAV applications could improve the available data sets (Bates et al., 2013).

Thus, this paper reports new data of aerosol and BC vertical profiles measured over $\mathrm{Ny}$-Ålesund (Svalbard islands) in 2 successive years (2011-2012) during an extensive field campaign (200 vertical profiles). Vertical profile measurements were conducted in the framework of the PRIN2009 ARCTICA project. The main part of the scientific activities at Ny-Ålesund was aimed at studying the chemical and physical properties of the aerosols and the long-range transport processes relevant for the measurements of organic and inorganic species at the site and along vertical profiles (Moroni et al., 2015; Udisti et al., 2013).

We describe first the sampling sites and the vertical profile measurements (Sect. 2). Results and discussion follow in Sect. 3, with the conclusions in the final Sect. 4.

\section{Methodology}

Tethered balloon soundings were carried out during spring 2011 and two summers (2011 and 2012) over NyÅlesund. The site is located at the Kongsfjorden, a fjord that develops in the northwest-southeast (NW-SE) direction. Northwards, Ny-Ålesund faces the sea, while a small chain of 400-500 $\mathrm{m}$ high mountains is located to the south (Fig. 1a).

Vertical profiles were measured from two sampling sites: during spring, the vertical profiles were taken at the Italian CNR Gruvebadet sampling site $\left(78^{\circ} 55^{\prime} 03^{\prime \prime} \mathrm{N}, 11^{\circ} 53^{\prime} 40^{\prime \prime} \mathrm{E}\right.$; Fig. 1b) to assure a large distance to the Ny-Ålesund village. During summer, the tethered balloon measurements were operated at the German-French AWIPEV research base $\left(78^{\circ} 55^{\prime} 24^{\prime \prime} \mathrm{N}, 11^{\circ} 55^{\prime} 15^{\prime \prime} \mathrm{E}\right)$ to lie in the proximity of the Ny-Ålesund harbor $(600 \mathrm{~m})$ allowing the measurement of ship plume diffusion (Sect. 3.3). Table 1 lists the dates of the campaign (25 measurement days), the number of flights (197 measured profiles), the maximum altitudes $(\sim 700$ 
Table 1. Dates, UTC, number of profiles, maximum altitude and sky conditions reached during the 2011-2012 spring-summer campaign in Ny-Ålesund.

\begin{tabular}{|c|c|c|c|c|}
\hline Date (dd-mm-yyyy) & Time in UTC & No. profiles & Max altitude (m) & Cloud base (m) \\
\hline \multicolumn{5}{|l|}{ Spring 2011} \\
\hline 30-03-2011 & $12: 40-15: 18$ & 6 & 741 & No clouds \\
\hline 01-04-2011 & $06: 30-17: 25$ & 10 & 788 & No clouds \\
\hline 04-04-2011 & $18: 17-20: 18$ & 6 & 748 & 1152 \\
\hline 06-04-2011 & $16: 42-19: 22$ & 8 & 716 & No clouds \\
\hline 07-04-2011 & $12: 51-19: 23$ & 10 & 712 & No clouds \\
\hline 08-04-2011 & $08: 25-19: 44$ & 14 & 740 & No clouds $/ 1534^{1}$ \\
\hline 10-04-2011 & $12: 45-14: 38$ & 6 & 300 & No clouds/984 ${ }^{2}$ \\
\hline 14-04-2011 & $15: 02-15: 58$ & 5 & 738 & No clouds \\
\hline 22-04-2011 & 19:17-20:09 & 4 & 846 & No clouds \\
\hline 23-04-2011 & $12: 10-13: 34$ & 6 & 1008 & 2414 \\
\hline 26-04-2011 & $16: 07-22: 00$ & 8 & 1152 & No clouds \\
\hline 30-04-2011 & 09:46-10:48 & 6 & 855 & 4018 \\
\hline \multicolumn{5}{|l|}{ Summer 2011} \\
\hline 06-07-2011 & $07: 40-17: 55$ & 10 & 1143 & No clouds $/ 2813^{3}$ \\
\hline 08-07-2011 & $16: 43-20: 53$ & 2 & 1208 & 1787 \\
\hline $12-07-2011$ & 08:19-10:01 & 6 & 724 & 506 \\
\hline \multicolumn{5}{|l|}{ Summer 2012} \\
\hline 21-06-2012 & $15: 12-16: 11$ & 2 & 980 & No clouds \\
\hline 23-06-2012 & $05: 55-11: 07$ & 12 & 1024 & 622 \\
\hline 24-06-2012 & $11: 02-15: 16$ & 8 & 1076 & No clouds \\
\hline 26-06-2012 & $07: 43-13: 00$ & 10 & 948 & No clouds \\
\hline 29-06-2012 & $07: 58-13: 19$ & 10 & 1144 & No clouds \\
\hline $30-06-2012$ & $09: 20-20: 30$ & 8 & 1100 & No clouds/821 4 \\
\hline 01-07-2012 & $08: 35-21: 40$ & 10 & 1212 & No clouds \\
\hline 04-07-2012 & $13: 30-18: 05$ & 8 & 1192 & 654 \\
\hline $10-07-2012$ & $08: 44-21: 07$ & 8 & 1268 & No clouds \\
\hline $11-07-2012$ & $08: 37-23: 20$ & 14 & 1196 & No clouds $/ 722^{5}$ \\
\hline
\end{tabular}

$1300 \mathrm{~m}$ ) and the cloud base height (clouds present for $48 \%$ of campaign). The aerosol and meteorological measurements were carried out both at ground and along the profiles as described in the following sections.

\subsection{Ground-based measurements}

Ground-based measurements were carried out at the Gruvebadet laboratory (Fig. 1b) where the distance $(1.2 \mathrm{~km}$ southern Ny-Ålesund) and the limitations established for snowmobile traffic and other potentially contaminant activities limits the impact from local emissions.

The Gruvebadet laboratory is equipped with a series of instruments aimed at measuring aerosol physical and optical properties, and collecting samples for chemical analysis (Sect. 2.1.1). The aerosol size distribution was measured using a scanning mobility particle sizer (TSI-SMPS 3034, 54 size classes, 10-487 nm) coupled with an aerody- namic particle sizer (TSI-APS 3321, 52 classes, 0.5-20 $\mu \mathrm{m}$ ). The two coupled systems measure one size spectrum every 10 min (Giardi et al., 2016). PM samples were collected by high-volume and low-volume samplers. For the purpose of the present paper, $\mathrm{PM}_{10}$ samples collected using two TECORA SkyPost low-volume samplers (EN 12341; $\mathrm{PM}_{10}$ sampling head, flow $2.3 \mathrm{~m}^{3} \mathrm{~h}^{-1}$; PTFE and quartz microfiber filters, $\varnothing=47 \mathrm{~mm}$ ) were considered. Sampling was carried out in ambient conditions: pressure and temperature were continuously monitored in order to maintain the constant flow rate of $2.3 \mathrm{~m}^{3} \mathrm{~h}^{-1}$. The first sampler collected $\mathrm{PM}_{10}$ for $24 \mathrm{~h}$ on Teflon filters (Pall R2PJ047) to determine the ionic fraction, while the second one collected $\mathrm{PM}_{10}$ for $96 \mathrm{~h}$ on pre-fired quartz microfiber filters (CHM QF1 grade) to determine organic and elemental carbon (Sect. 2.1.1). The Teflon filters were conditioned for $48 \mathrm{~h}\left(25^{\circ} \mathrm{C}\right.$ and $50 \%$ relative humidity) before and after the sampling, then weighted by a five-digit microbalance (Sartorius ME235P). The reproducibility error 


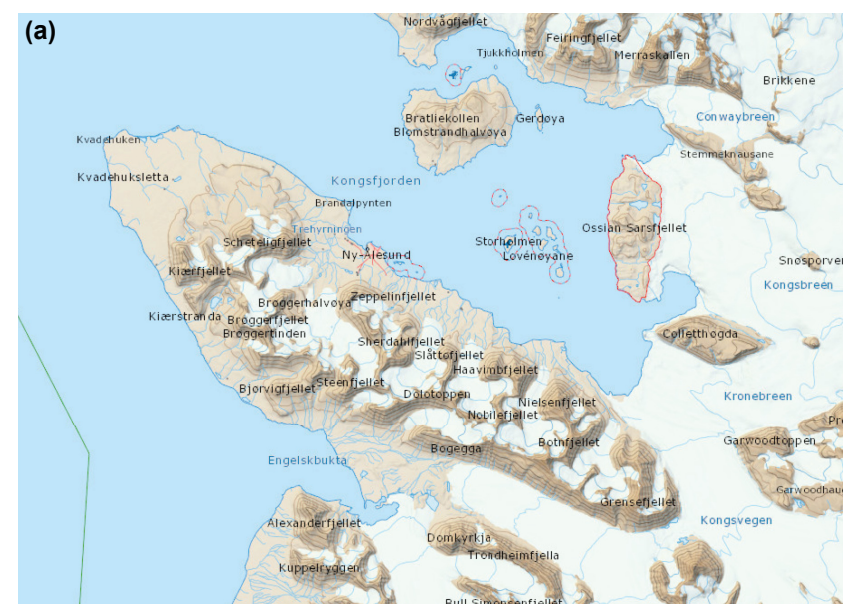

(b)
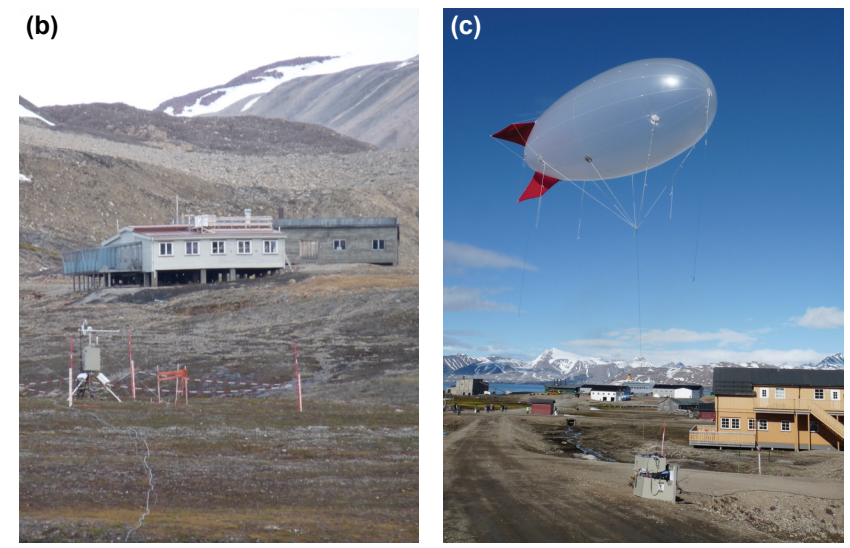

Figure 1. (a) Ny-Ålesund, the Kongsfjord and the surrounding orography; (b) Gruvebadet sampling site; (c) the tethered balloon in Ny-Ålesund.

for filter weighing was lower than $5 \%$ (experimentally evaluated). After sampling, filters were individually sealed in prewashed (with Milli-Q water, $18.3 \mathrm{M} \Omega \mathrm{cm}$ ) polystyrene filter containers and stored at $-20^{\circ} \mathrm{C}$ until analysis.

\subsubsection{Aerosol chemistry measurements at ground level}

$\mathrm{PM}_{10}$ samples collected at ground level at Gruvebadet were analyzed to determine first the water-soluble ionic fraction. Half of each $\mathrm{PM}_{10}$ Teflon filter was extracted in $10 \mathrm{~mL}$ of ultrapure water (Milli-Q, $18.3 \mathrm{M} \Omega \mathrm{cm}$ resistivity) by ultrasonic bath for $20 \mathrm{~min}$. Filters manipulation was carried out under a class-100 laminar-flow hood, in order to minimize contamination risks. Inorganic cations and anions together with organic anions, were simultaneously measured by a triple Dionex ion-chromatography system, equipped with electrochemical-suppressed conductivity detectors. Cations $\left(\mathrm{Na}^{+}, \mathrm{NH}_{4}^{+}, \mathrm{K}^{+}, \mathrm{Mg}^{2+}\right.$ and $\left.\mathrm{Ca}^{2+}\right)$ have been determined by a Dionex CS12A-4 mm analytical column with $20 \mathrm{mM}$ $\mathrm{H}_{2} \mathrm{SO}_{4}$ eluent. Anions $\left(\mathrm{Cl}^{-}, \mathrm{NO}_{3}^{-}, \mathrm{SO}_{4}^{2-}\right.$ and $\left.\mathrm{C}_{2} \mathrm{O}_{4}^{2-}\right)$ were measured by a Dionex AS4A $4 \mathrm{~mm}$ analytical column with a $1.8 \mathrm{mM} \mathrm{Na} \mathrm{CO}_{3} / 1.7 \mathrm{mM} \mathrm{NaHCO} 3$ eluent, while $\mathrm{F}^{-}$ and some organic anions (acetate, glycolate, formate and methanesulfonate) were determined by a Dionex AS11 separation column by a gradient elution $(0.075$ to $2.5 \mathrm{mM}$ $\mathrm{Na}_{2} \mathrm{~B}_{4} \mathrm{O}_{7}$ eluent) (Udisti et al., 2004; Becagli et al., 2011).

The detection limit $\left(\mathrm{ng} \mathrm{m}^{-3}\right)$ of each analyzed chemical component is reported in the Supplement (Table S1) together with the measured ambient ion concentrations. All the analyzed chemical components were largely above the detection limit.

The contribution of sea salt and crustal components in Ny-Ålesund is not-negligible (Udisti et al., 2016; Giardi et al., 2016; Moroni et al., 2015). Thus, $\mathrm{Na}^{+}, \mathrm{Ca}^{2+}$ and $\mathrm{SO}_{4}^{2-}$ (which originate from both these sources) were apportioned between sea-salt (ss) and non-sea-salt (nss) fractions on the basis of known $w / w$ (weight / weight) ratios in sea water and Earth crust (Udisti et al., 2012, 2016; Giardi et al., 2016; Becagli et al., 2012):

$$
\begin{aligned}
& \text { tot }-\mathrm{Na}^{+}=\mathrm{ss}-\mathrm{Na}^{+}+\mathrm{nss}-\mathrm{Na}^{+} \\
& \text {tot }-\mathrm{Ca}^{2+}=\mathrm{ss}-\mathrm{Ca}^{2+}+\mathrm{nss}-\mathrm{Ca}^{2+} \\
& \mathrm{ss}-\mathrm{Na}^{+}=\text {tot }-\mathrm{Na}^{+}-0.562 \mathrm{nss}-\mathrm{Ca}^{2+} \\
& \mathrm{nss}-\mathrm{Ca}^{2+}=\text { tot }-\mathrm{Ca}^{2+}-0.038 \mathrm{ss}-\mathrm{Na}^{+},
\end{aligned}
$$

where 0.562 represents the $w / w \mathrm{Na}^{+} / \mathrm{Ca}^{2+}$ ratio in the crust (Bowen, 1979) and 0.038 is the $\mathrm{Ca}^{2+} / \mathrm{Na}^{+} w / w$ ratio

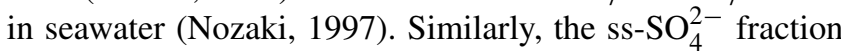
was calculated from the ss- $\mathrm{Na}^{+}$using the $0.253 \mathrm{SO}_{4}^{2-} / \mathrm{Na}^{+}$ $w / w$ ratio in seawater (Bowen, 1979). The crustal fraction of

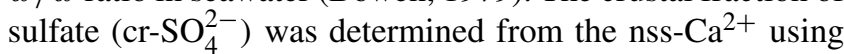
the $0.59 \mathrm{SO}_{4}^{2-} / \mathrm{Ca}^{2+} w / w$ ratio in the uppermost Earth crust (Wagenbach et al., 1996). Finally, the nss-nc-SO ${ }_{4}^{2-}$ fraction, which can be due to anthropogenic or secondary formed

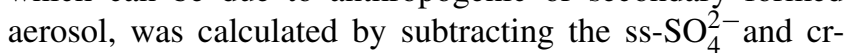
$\mathrm{SO}_{4}^{2-}$ contributions from the total $\mathrm{SO}_{4}^{2-}$ concentrations.

The organic carbon (OC) and elemental carbon (EC) fractions were determined in $\mathrm{PM}_{10}$ samples using a thermooptical transmission (TOT) method following the NIOSH protocol. The organic matter $(\mathrm{OM})$ was calculated by multiplying the OC fraction by 2.1 (Turpin and Lim, 2001) typical for remote sites with a large fraction of secondary aerosols. Table S1 also reports the detection limit for EC and OC.

\subsubsection{Meteorological context}

Meteorological parameters are currently measured at different sites in Ny-Ålesund. The German-French AWIPEV research base operates surface meteorology measurements with $1 \mathrm{~min}$ time resolution, including temperature and relative humidity at $2 \mathrm{~m}$ height, wind speed and direction at $10 \mathrm{~m}$ height and pressure at station level close to the summer campaign balloon launch site (Maturilli et al., 2013). The cloud base height above the station is retrieved using a Vaisala LD-40 ceilometer. Daily radiosoundings (11:00 UTC) by the 
AWIPEV observatory provide auxiliary data for the aerosol profile analysis.

Since 2009, the Italian National Research Council (CNR) has operated the Amundsen-Nobile climate change tower (CCT), providing meteorological, micrometeorological, radiation and snow measurements continuously all year long (Mazzola et al., 2016a). Conventional and micrometeorological parameters are measured at different heights (4 and $3 \mathrm{lev-}$ els, respectively) in order to investigate their vertical variations in different conditions. Dai et al. (2011) and Mazzola et al. (2016b) found that both in the Adventfjorden and in Kongsfjorden, where Ny-Ålesund is located, the atmosphere is stable for about $50 \%$ of the time during the year, by analyzing micrometeorological data. The term stability refers to the propensity of air masses to move vertically: stable air resists any vertical motion, while unstable air masses are prone to vertical movements. A parcel of air is stable/unstable if the temperature lapse rate is lower/higher than the adiabatic one, i.e., if the potential temperature is increasing/decreasing with height, respectively. In stable stratification, turbulence and vertical mixing are suppressed, leading to trapping of pollutants near ground level. On the above grounds, the spring 2011, summer 2011 and summer 2012 campaign periods can be put into a climatological context.

\subsection{Vertical profile measurements}

Vertical profile measurements have been carried out by means of a kytoon-shaped, helium-filled tethered balloon (length $8 \mathrm{~m}, \varnothing=3 \mathrm{~m}$, volume $55.0 \mathrm{~m}^{3}$, payload $25 \mathrm{~kg}$; Fig. 1c). The tethered balloon was designed to fly in severe wind conditions. However, the presence of the payload limits the balloon flights from low to moderate wind conditions $\left(<10 \mathrm{~m} \mathrm{~s}^{-1}\right)$.

The tethered balloon was equipped with an instrumental package consisting of

1. an optical particle counter (OPC GRIMM 1.107; 31 size classes between 0.25 to $32 \mu \mathrm{m}, 6 \mathrm{~s}$ sampling time) for the particle number size distribution determination;

2. a miniaturized electrical particle detector (miniDiSC, Matter Aerosol) to measure the total particle number concentration (1 s sampling time);

3. two micro-aethalometers: the microAeth ${ }^{\circledR}$ AE51 and a prototype (1-60 s sampling time);

4. a meteorological station (LSI-Lastem: pressure, temperature and relative humidity, $6 \mathrm{~s}$ sampling time).

During the period 11-30 April 2011, the Vaisala tethersonde TTS111 (pressure, temperature, relative humidity, wind speed and wind direction; $1 \mathrm{~s}$ sampling time) was also used.

The maximum height reached during each flight depended on atmospheric conditions and, for the majority of the profiles, was between 0.7 and $1.3 \mathrm{~km}$. An electric winch controlled the ascent/descent rates that were set at $40.0 \pm 0.1 \mathrm{~m} \mathrm{~min}^{-1}$.

A deeper description of each instrument is reported below.

\subsubsection{Size distribution data}

In this study, the total aerosol concentration and the number size distribution along height were measured using a coupled $\operatorname{miniDiSC}-\mathrm{OPC}(\lambda=655 \mathrm{~nm})$ system.

The miniDiSC is a miniature diffusion size classifier, a small and portable instrument $(4 \times 9 \times 18 \mathrm{~cm}, 670 \mathrm{~g}, 8 \mathrm{~h}$ of battery supply) (Fierz et al., 2011). The aerosol is first charged in a standard positive unipolar diffusion charger (the average charge is approximately proportional to the particle diameter). The charged particles flow through a diffusion stage (an electrically insulated stack of stainless steel screens connected to a sensitive electrometer that collect the finest particles) and into a second stage (equipped with a HEPA filter) where the current of larger particles is measured with an electrometer. The miniDiSC has a $d_{50}$ cutoff at $14 \mathrm{~nm}$. Thus, the instrument underestimates particle number concentrations for particles smaller than $20 \mathrm{~nm}$ (nucleation mode). As a result, the miniDiSC counts only partially the nucleation mode, while it allows a whole determination of Aitken and accumulation-mode particles. As demonstrated by Fierz et al. (2011), a bimodal lognormal aerosol size distribution with a fixed accumulation mode at $100 \mathrm{~nm}$ and a varying nucleation mode at $20 \mathrm{~nm}$ introduces an underestimation of about -2 to $10 \%$ of the total aerosol concentration in the miniDiSC response. The particle number determination is robust, and the error never exceeds $20 \%$.

The OPC used in the campaign was the model Grimm 1.107 that counts and classifies the aerosol in 31 size classes between $250 \mathrm{~nm}$ and $32 \mu \mathrm{m}$. As reported in the literature (Ferrero et al., 2014; Howell et al., 2006; Heyder and Gebhart, 1979), OPC size classification of the aerosol particles is a function of their ability to scatter the laser light under the assumption of spherical particles. The aerosol particles are classified in terms of their optical equivalent diameter, which is defined as "the diameter of a sphere of known refractive index (that of polystyrene latex spheres used for of calibration) that scatters light as efficiently as the real particle in question". This effect usually results in an undersizing of the size classification, due to the higher refractive index of the polystyrene latex spheres (PSL spheres, $m=1.58$ at $655 \mathrm{~nm}$; Ma et al., 2003) used in the OPC calibration compared to ambient aerosol (Guyon et al., 2003; Liu and Daum, 2008; Schumann, 1990). In order to derive a proper size classification of the aerosol over Svalbard, the undersizing issue was solved by correcting the OPC size channels to account for the ambient aerosol refractive index $m$. The OPC response function ( $S$ : the partial light-scattering cross section of the particle related to the specific optical design of the OPC) was computed at $655 \mathrm{~nm}$ as follows (Baron and Willeke, 2005; 
Heyder and Gebhart, 1979):

$$
S\left(\theta_{0}, \Delta \Omega, x, m\right)=\frac{\lambda^{2}}{4 \pi^{2}} \iint_{\Delta \Omega} i(\theta, \Phi, x, m) \sin \theta \mathrm{d} \theta \mathrm{d} \Phi,
$$

where $\theta_{0}$ represents the mean scattering angle of the optical arrangement, $\Delta \Omega$ the receiver aperture, $x$ the dimensionless size parameter, $m$ the refractive index and $i(\theta, \varphi, x, m)$ the Mie scattering function composed by the perpendicular and parallel components $i_{1}(\theta, x, m)$ and $i_{2}(\theta, x, m)$, respectively. The optical arrangement of the OPC 1.107 consists of (1) a wide angle parabolic mirror $\left(121^{\circ}\right.$, from 29.5 to $150.5^{\circ}$, $\theta_{0}=90^{\circ}$ ) that focuses scattered light on the photodetector located on the opposite side; (2) $18^{\circ}$ of direct collected scattered light on the photodetector (from 81 to $99^{\circ}, \theta_{0}=90^{\circ}$ ) (Heim et al., 2008).

The response function was calculated both for PSL spheres $\left(S_{\mathrm{PSL}}\right)$ and for ambient aerosol $\left(S_{\mathrm{AMB}}\right)$. The refractive indexes of ambient aerosol used in $S_{\mathrm{AMB}}$ calculations were obtained from the closest AERONET site (Horsund; $77^{\circ} 00^{\prime} 04^{\prime \prime} \mathrm{N}, 15^{\circ} 33^{\prime} 37^{\prime \prime} \mathrm{E}$ ) for spring 2011 and summer 2011-2012: $1.544+0.013 i$ and $1.535+0.015 i$, respectively. These refractive indexes were determined at $674 \mathrm{~nm}$ (the closest AERONET wavelength to the OPC laser wavelength of $655 \mathrm{~nm}$ ) and were close to those determined at $530 \mathrm{~nm}$ at Gruvebadet site (range 1.4-1.8 during 2010 and 2011; Lanconelli et al., 2013). Table S2 shows the new size-corrected channels in comparison with the PSL spheres' equivalent ones. The new channels were used to define three broad size ranges (detailed below) to evaluate the vertical behavior of aerosol.

The coupled miniDiSC-OPC $(\lambda=655 \mathrm{~nm})$ system measurement range covers the relevant region of the aerosol number size distribution. In order to study the behavior of different size classes along height, three aerosol number concentration size ranges were selected:

1. the number concentration of aerosol between $14 \mathrm{~nm}$ ( $d_{50}$ of miniDiSC) and $260 \mathrm{~nm}$ (cf. Table S2) obtained as the difference between the total number concentration measured by the miniDiSC and that measured by the OPC, hereinafter indicated as $N_{14-260}$;

2. the number concentration of aerosol between $260 \mathrm{~nm}$ (lower limit of OPC) and $1200 \mathrm{~nm}$ hereinafter indicated as $N_{260-1200}$;

3. the number concentration of aerosol above $1200 \mathrm{~nm}$, hereinafter indicated as $N_{>1200}$.

The mode $N_{14-260}$ includes a small fraction of the nucleation mode (from 14 to $20 \mathrm{~nm}$ ), the totality of the Aitken mode (20-100 nm) and a fraction of the accumulation mode (from 100 to $260 \mathrm{~nm}$ ). The mode $N_{260-1200}$ includes most of the accumulation-mode particles. Finally, mode $N_{>1200}$ covers the totality of giant nuclei mode.
The accuracy of both miniDiSC and OPC measurements was investigated comparing the lowermost portion of their measurements along vertical profile with SMPS + APS data collected at ground level at Gruvebadet. This comparison was performed during spring 2011 to avoid any contamination from ship plumes arriving from Ny-Ålesund harbor towards Gruvebadet in summer (balloon soundings were conducted from the Koldewey station instead of from Gruvebadet; Sect. 2.1). The comparison of $N_{14-260}$ (miniDiSC vs. SMPS) and of $N_{>260}$ (OPC vs. SMPS + APS) was characterized by an excellent correlation $\left(R^{2}>0.9\right.$; linear best fit close to the ideal one) with an average error of 7 and $16 \%$ for both $N_{14-260}$ and $N_{>260}$, respectively (Fig. S1a-b in the Supplement). These results highlight the reliability of measurements carried out along the vertical profiles, an important feature considering the low aerosol concentration values and their variation, which are present within the Arctic (Sect. 1).

Number concentration data were also used in Sect. 3.2.4 to estimate the contribution of locally formed aerosol. The method is based on the $N$ / BC ratio, developed by Rodríguez and Cuevas (2007) and successfully applied in Europe by Reche et al. (2011). The basic concept of this method is that highest values of $N / \mathrm{BC}$ ratios (i.e., the lowest $\mathrm{BC}$ fraction values) occur during secondary aerosol formation in the atmosphere (Reche et al., 2011; Dall'Osto et al., 2011, 2013). The methodology is as follows:

$N_{2}=N-N_{1}$

$N_{1}=S_{1} \times \mathrm{BC}$,

where $N_{2}$ represents the secondary aerosol concentration locally formed in the atmosphere, $N$ is the measured aerosol number concentration and $N_{1}$ is the aerosol number concentration already present in the background air. $S_{1}$ represents a reference value for the $N / \mathrm{BC}$ ratio (expressed as particles $\mathrm{cm}^{-3} \mathrm{ng}^{-1} \mathrm{~m}^{-3}$ of $\mathrm{BC}$ ) in the background air. The parameter $N_{1}$ is calculated from the parameter $S_{1}$ multiplied by the measured BC concentration (see Sect. 2.2.2). $S_{1}$ can vary from $\sim 2$ to $\sim 9$, while the $N / \mathrm{BC}$ ratio during secondary aerosol formation reaches values higher than $\sim 15$ 20 and up to $\sim 100-200$ (Reche et al., 2011; Dall'Osto et al., 2011, 2013). The differences in $S_{1}$ values determined in different sites can be caused by (1) the use of different particle counters (with different $d_{50}$ cutoff), as lowest $S_{1}$ values are usually observed when devices with largest $d_{50}$ cutoff are used; (2) the influence of the ambient air conditions on the secondary aerosol formation. Thus, $S_{1}$ is site instrument specific and has to be determined onsite depending on the used particle counter. If the Rodríguez and Cuevas (2007) method is applied to ground-based temporal data series, $S_{1}$ can be obtained as the minimum $N$ vs. BC slope observed during the day (Reche et al., 2011). However, in the case of measured vertical profiles, the values of $S_{1}$ were taken as that of background aerosol above the aerosol stratifications described in Sect. 3.2.4. 


\subsubsection{Black carbon}

$\mathrm{BC}$ have been determined using two micro-aethalometers: the microAeth ${ }^{\circledR}$ AE51 and a prototype (Magee Scientific; $250 \mathrm{~g}, 117 \times 66 \times 38 \mathrm{~mm}^{3}$ ). Adopting the nomenclature recommended by Petzold et al. (2013), by Andreae and Gelencser (2006) and by other authors (Gilardoni et al., 2011; Stohl et al., 2013; Eckhardt et al., 2013), we refer to the measured parameter as equivalent black carbon $(\mathrm{eBC})$ due to the absence of an overall agreed reference material, linking light absorption to the empirically defined BC mass concentration. In agreement with the above cited literature, we also report the absorption coefficient values.

AE51 and the prototype were identical with the exception that the prototype measured at $2 \lambda(370$ and $880 \mathrm{~nm}$ ) while AE51 only at $880 \mathrm{~nm}$. At the time of campaign the prototype had just been developed and was used instead the AE51 on the balloon platform during the spring 2011 campaign only when necessary (i.e., AE51 in charge) to ensure the continuity of measurements during the campaign.

In both the aethalometers, the aerosol containing $\mathrm{BC}$ was continuously sampled onto a PTFE-coated borosilicate glass fiber filter (Fiberfilm ${ }^{\mathrm{TM}}$ filters, Pall Corporation) where the light attenuation (ATN) was measured at $880 \mathrm{~nm}$ relative to a clean part of the filter. ATN was calculated as

$\mathrm{ATN}=100 \cdot \ln \left(I_{0} / I\right)$,

where $I_{0}$ and $I$ are the light intensities transmitted throughout a reference blank spot and the aerosol-laden $3 \mathrm{~mm}$ diameter sample spot of the filter, respectively.

The attenuation coefficient of the particles collected on the filters, $b_{\mathrm{ATN}}$, was derived from ATN as follows (Weingartner et al., 2003):

$b_{\mathrm{ATN}}=\frac{A}{100 Q} \frac{\Delta \mathrm{ATN}}{\Delta t}$,

where $\triangle \mathrm{ATN}$ indicates the ATN variation during the time period $\Delta t, A$ is the sample spot area $\left(7.1 \times 10^{-6} \mathrm{~m}^{2}\right)$ and $Q$ is the volumetric flow rate $\left(2.5 \times 10^{-6} \mathrm{~m}^{3} \mathrm{~s}^{-1}\right.$ for the AE51 and $4.42 \times 10^{-6} \mathrm{~m}^{3} \mathrm{~s}^{-1}$ for the prototype).

Finally, to determine the eBC ambient concentration the apparent mass attenuation cross section $\left(\sigma_{\mathrm{ATN}}=\right.$ $12.5 \mathrm{~m}^{2} \mathrm{~g}^{-1}$ ) is needed; it is defined for the eBC collected on the PTFE-coated borosilicate glass fiber filter. The $\sigma_{\mathrm{ATN}}$ value $\left(12.5 \mathrm{~m}^{2} \mathrm{~g}^{-1}\right)$ was obtained by comparing the eBC values measured with the microAeth ${ }^{\circledR}$ model AE51, with an AE31 aethalometer ( $880 \mathrm{~nm}$ wavelength) operating in a test chamber with different eBC concentrations at low attenuation values. The comparison was then repeated using ambient air (Ferrero et al., 2011a). This value is not far from the $\sigma_{\mathrm{ATN}}$ values of 15.2 and $15.9 \mathrm{~m}^{2} \mathrm{~g}^{-1}$ reported in Eleftheriadis et al. (2009) which recorded 10 years of eBC measurements in Ny-Ålesund at the Zeppelin station with the aethalometers AE9 and AE31. The difference between these values results from the use of different filter materials to collect the sample in the different aethalometers, which was quantified in Ferrero et al. (2011a) and Drinovec et al. (2015).

The eBC concentrations were determined as follows:

$\mathrm{eBC}=\frac{b_{\mathrm{ATN}}}{\sigma_{\mathrm{ATN}}}$.

The accuracy of eBC measurement was investigated. The AE51 and the prototype measurements carried out simultaneously agreed very well $\left(R^{2}=0.852\right.$; slope $=0.976$; Fig. S1c). This result was important as it was obtained with two different flow rates $\left(2.5 \times 10^{-6} \mathrm{~m}^{3} \mathrm{~s}^{-1}\right.$ for the AE51 and $4.42 \times 10^{-6} \mathrm{~m}^{3} \mathrm{~s}^{-1}$ for the prototype).

However, a large scatter is present at low eBC concentrations (i.e., 10-20 $\mathrm{ng} \mathrm{m}^{-3}$; see Fig. S1c). Thus, the absolute error (in percentage) of each $\mathrm{eBC}$ value (considering the average of the two aethalometers) was calculated for intervals of $5 \mathrm{ng} \mathrm{m}^{-3}$ of concentrations. At low concentrations, the error can reach up to $90 \%$ and more (Fig. S2a). This error decreases with increasing concentration, dropping below $20 \mathrm{ng} \mathrm{m}^{-3}$ for eBC concentrations above $5 \mathrm{ng} \mathrm{m}^{-3}$. The relative error lies below $20 \%$ for both the average and the 90th percentile at $\mathrm{eBC}$ concentrations above $20 \mathrm{ng} \mathrm{m}^{-3}$. Thus, it is possible to consider this value as the limit above which a single eBC measurement point is not affected by instrumental noise. Nevertheless, this limit is close to the BC concentrations that have been previously measured in the Arctic (Eleftheriadis et al., 2009). In this respect, we note that the $\mathrm{BC}$ profiles presented in the paper are an average of many measurements, hence the effect of the noise on the reported $\mathrm{eBC}$ concentrations is further reduced. The aim of this paper is to determine the seasonal phenomenology of the aerosol behavior along vertical profiles, classifying the collected experimental data according to their shape and averaging them for each season. This is very important as even though the error in percentage of each data point can reach high values (especially at low concentrations), the average of the data stabilizes the instrumental fluctuations. This effect is demonstrated by Fig. S2b which reports the correlation between the BC concentrations (AE51 and prototype) averaged on the same intervals of $5 \mathrm{ng} \mathrm{m}^{-3}$ used in Fig. S2a $\left(R^{2}=0.986\right.$; slope $=1.017$ ).

The above-reported analysis underlines a critical situation for summer because, as reported in Eleftheriadis et al. (2009), the eBC concentration range expected in summer is $\sim 0$ $10 \mathrm{ng} \mathrm{m}^{-3}$. Therefore, summer eBC data were used here only to highlight the impact of shipping emissions on the Arctic background concentrations along the atmospheric column. Due to high ship impact (Sect. 3.4), the performance of the micro-aethalometers was suitable and reliable for the purpose of this application.

In addition to $\mathrm{eBC}$, the micro-aethalometers also allow the determination of the aerosol absorption coefficient, $b_{\mathrm{abs}}$, that 
was calculated as follows:

$b_{\mathrm{abs}}=\frac{b_{\mathrm{ATN}}}{C \cdot R(\mathrm{ATN})}$,

where $C$ and $R(\mathrm{ATN})$ are the multiple scattering optical enhancement factor and the aerosol loading factor, respectively. Briefly, the constant optical enhancement factor $C$ compensates for the enhanced optical path through the filter caused by multiple scattering induced by the filter fibers themselves (Schmid et al., 2006; Arnott et al., 2005; Weingartner et al., 2003). The parameter $R(\mathrm{ATN})$ compensates for the nonlinearity - the loading effect due to reduction of the measurement sensitivity due to the saturation caused by the collected sample on the filter. The compensation with the parameter $R(\mathrm{ATN})$ is needed only when ATN becomes higher than 20 (Schmid et al., 2006; Arnott et al., 2005; Weingartner et al., 2003). In this study, the experimental design allowed us to neglect the use of $R(\mathrm{ATN})$ : all eBC vertical profiles were conducted in the clean Arctic environment and the filter tickets were changed regularly to always keep ATN lower than 20 as recommended by Weingartner et al. (2003). For the AE51 and the prototype, the only parameter $C$ available in the literature is $2.05 \pm 0.03$ (at $\lambda=880 \mathrm{~nm}$ ) (Ferrero et al., 2011a), even though recently Ran et al. (2016) proposed a $C$ value of 2.52 for ground-based measurements in China.

The $C$ value of $2.05 \pm 0.03$ was determined over Milan in Ferrero et al. (2011a) and thus a brief description is necessary to determine its applicability in the Arctic area. The parameter $C$ was determined using data collected both below the mixing layer and above it, in a cleaner atmosphere, along the vertical profiles (Ferrero et al., 2011a). During the $C$ determination, a new filter ticket was used for each profile. As a result, ATN never reached values higher than 20 (average ATN was $5 \pm 1$ ) and the total amount of aerosol collected on each filter during the $C$ determination was negligible. Therefore, the determined $C$ was exclusively dependent on the filter material and the AE51 instrumental geometry. This ensures the negligible influence of the particles in the filter matrix on the $C$ value. The reliability of the obtained $C(2.05 \pm 0.03)$ was demonstrated in Ferrero et al. (2014) below the mixing layer and in free troposphere.

Finally, it should be noted that absorbing non-BC particles may contribute to the signal in aethalometers (i.e., brown carbon, dust). However, $\mathrm{BrC}$ is characterized by negligible absorption in the infrared (Andreae and Gelencsér, 2006), which is the wavelength range of the eBC measurements (microAeth AE51 uses $880 \mathrm{~nm}$ ). In this respect, Massabò et al. (2015) showed the potential contribution of $\mathrm{BrC}$ to the determination of eBC to be below $10 \%$.

To estimate the possible influence of $\mathrm{BrC}$ on eBC measurements carried out during the spring 2011 campaign, the data collected with the microAeth prototype at 370 and $880 \mathrm{~nm}$ were considered. They highlighted a $\mathrm{BrC}$ positive artifact on eBC measurements less than $10 \%$ during the campaign. Details are reported in the Supplement.

\subsubsection{Meteorological data and aerosol stratifications}

Meteorological data along height allowed the determination of the absolute height of the balloon using the hypsometric equation; due to a change in April 2011 in the measuring system (Sect. 2.2), a comparison of the altitude obtained by the LSI-Lastem and Vaisala tethersonde was conducted during several target flights. The result $\left(R^{2}=0.997\right.$; slope $=0.999$; Fig. S1d) demonstrated the accuracy of the height determination. The measurement of altitude is fundamental in the study of the vertical aerosol properties in relationship to meteorological parameters. In fact, vertical aerosol profiles allow the determination of the height of aerosol stratifications by means of a gradient method applied to aerosol concentration profiles, as suggested by Seibert et al. (2000).

The gradient method is based on the determination of the minimum value of the vertical derivative of the aerosol concentration. The use of gradient method to determine the aerosol mixing height has been demonstrated at lower latitudes in previous works (Ferrero et al., 2007, 2011a, b, and 2012; Sangiorgi et al., 2011; Di Liberto et al., 2012). However, in remote areas such as the Arctic, several processes other than dispersion can shape the aerosol profiles. The two most important ones are (1) differential advection (Tunved et al., 2013) and (2) a lack of emission of aerosol from ground. These processes should generate a vertical structure not directly related to the $\mathrm{PBL}$ height.

Therefore, in the present work the gradient method has been limited to individuate aerosol stratification heights $\left(A S_{h}\right)$, even if these related to the behavior of meteorological variables governing the behavior of the PBL as will be addressed in Sect. 3.1.

The $\mathrm{AS}_{\mathrm{h}}$ will be used in the next sections to calculate averaged aerosol and eBC profiles (Sect. 3.2 and 3.3). In fact, in order to investigate the variation of aerosol properties with height, vertical profiles were statistically averaged. As reported in previous works (Ferrero et al., 2011a, 2012, 2014), a way to average vertical profile data by taking their main gradients $\left(\mathrm{AS}_{\mathrm{h}}\right)$ into account is to consider the relative position of each measured data point in respect to the $A S_{h}$. Thus, vertical profiles were first normalized, introducing a standardized height $\left(H_{\mathrm{S}}\right)$ calculated as follows:

$H_{\mathrm{s}}=\frac{z-\mathrm{AS}_{\mathrm{h}}}{\mathrm{AS}_{\mathrm{h}}}$

where $z$ is the height above ground. $H_{\mathrm{s}}$ assumes a value of 0 at the $A S_{\mathrm{h}}$ and values of -1 and 1 at ground level and at twice the $\mathrm{AS}_{\mathrm{h}}$, respectively.

Examples of $\mathrm{AS}_{\mathrm{h}}$, accompanied with the corresponding potential temperature $(\theta)$ and $\mathrm{RH}$ profiles, are presented in Fig. $2 \mathrm{a}-\mathrm{d}$. The presented data accurately describe the vertical distribution of the aerosol and its properties in the first kilometer above Ny-Ålesund. Moreover, they allowed obtaining different pieces of information. 

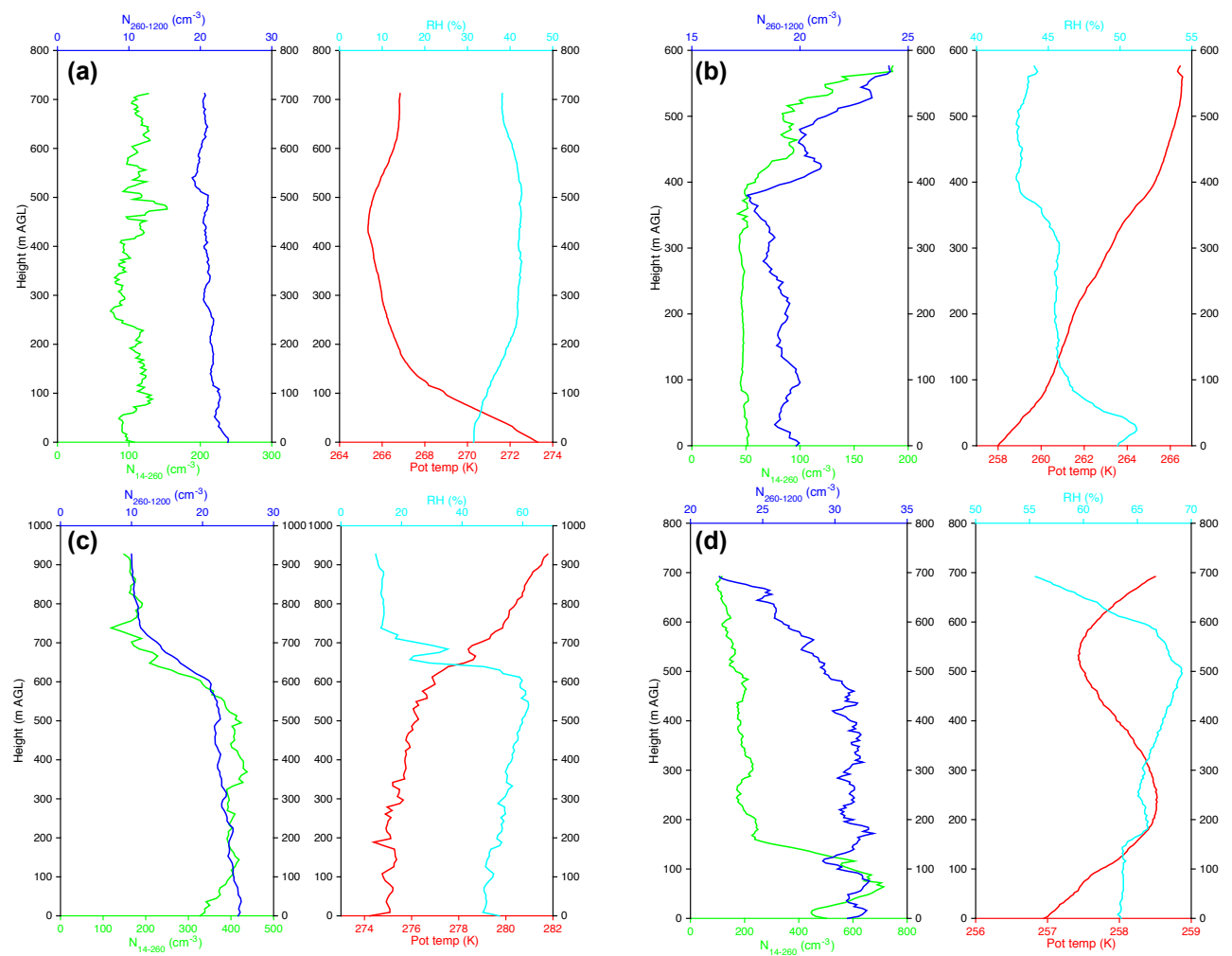

Figure 2. Vertical profiles of $N_{14-260}$ (green line), $N_{260-1200}$ (blue line), potential temperature (red line) and relative humidity (light blue line) measured over Ny-Ålesund on (a) 7 April 2011 (12:51-13:10 UTC); (b) 1 April 2011 (06:30-06:57 UTC); (c) 23 April 2011 (13:21-13:34 UTC); (d) 6 April 2011 (18:03-18:22 UTC).

The absence or the presence of marked aerosol stratifications (AS) is notable. When present, the altitude at which they occur $\left(\mathrm{AS}_{\mathrm{h}}\right)$ was determined by the gradient method, described above. This is the first obtainable information.

A second piece of information was the size-dependent vertical behavior of aerosol concentrations. Figure $2 \mathrm{~b}$ and $\mathrm{c}$ highlight a similar behavior for both $N_{14-260}$ and $N_{260-1200}$, while Fig. $2 d$ shows different behavior for $N_{260-1200}$ due to a concentration change located at a different altitude. Finally, we obtained the magnitude of the observed concentration change at each $\mathrm{AS}_{\mathrm{h}}$ for each size range $\left(N_{14-260}\right.$, $N_{260-1200}$ and $N_{>1200}$ ) and season.

The analysis and combination of these three types of information allowed to classify, as a function of seasonality, the altitude, magnitude and frequency of aerosol stratifications. Furthermore, it has been possible to shed some light on the dynamics underlying the seasonal phenomenology found during the field campaigns. A detailed discussion of these points is reported in the following section.

\section{Results and discussion}

Vertical profiles of aerosol number size distribution and eBC concentrations were measured to assess changes in aerosol properties within the vertical column in the Arctic region. The results obtained along vertical profiles are discussed in order to first highlight the vertical behavior of the $\mathrm{AS}_{\mathrm{h}}$ in relation to the main atmospheric meteorological parameters (Sect. 3.1). Then, vertical aerosol properties are discussed in details for springtime (Sect. 3.2) and summertime (Sect. 3.3). All averaged data are reported hereinafter as mean \pm mean standard deviation.

\subsection{Aerosol stratifications: seasonal vertical frequency distribution and relationship with meteorology}

As reported in Table 1, about 200 profiles were measured during three campaigns in spring 2011, summer 2011 and summer 2012. Here, the ambient conditions under which the vertical profiles were measured are briefly described.

First of all, the observational periods (spring 2011, summer 2011 and summer 2012) were addressed in a climatological context. In this respect, the temperature measured in spring 2011 was within the standard deviation range of the long-term observations, while a 10-day period at the end of April 2011 was slightly warmer than the climatological mean (Fig. S3a). The temperatures during the summer seasons 2011 and 2012 were mostly within the range of the longterm observations (Fig. S3b). Neither of the campaign peri- 
ods was conducted under exceptional meteorological conditions, so the vertical profile measurements can be considered to have been obtained under typical meteorological conditions representative for the $\mathrm{Ny}$-Ålesund environment.

We note, however, that the tethered balloon measurements have limitations with respect to the balloon's launch conditions (Sect. 2.2). Particularly, balloon profiles were measured in low-wind conditions, as it is very difficult to launch the balloons during high winds. This introduces a bias in respect to average meteorological conditions above the launch site. The maximum wind speed measured at the AmundsenNobile climate change tower (Sect. 2.1.2) during balloon flights was lower than that during the whole period of the campaign (April 2011, June and July 2011 and 2012): 4.9 and $10.7 \mathrm{~m} \mathrm{~s}^{-1}$ (springtime and summertime balloon profiles) compared to 27.9 and $16.3 \mathrm{~m} \mathrm{~s}^{-1}$ (full spring 2011 and summers 2011 and 2012). Table 1 resumes the conditions for all the measured profiles. The majority of vertical profile measurements was conducted under clear sky conditions (no clouds) or with clouds with base height above the balloon payload.

Thus, it is possible to assert that the measured profiles and the seasonal phenomenology described hereinafter are representative of typical Arctic springtime and summertime periods mainly for low wind and clear sky conditions.

Figure 2a-d highlight different atmospheric dispersal conditions upon Ny-Ålesund. Although these four case studies are not illustrative and comprehensive of the whole data set, their discussion helps to illustrate the seasonal and sizedependent behavior of the frequency distribution of the $\mathrm{AS}_{\mathrm{h}}$ with altitude.

An example of homogeneous dispersion of aerosol (independent from its size) in the lower troposphere is shown in Fig. 2a. Decreasing potential temperature with height indicates atmospheric instability, allowing the vertical mixing of air masses by convection. Homogeneous aerosol profiles with convective conditions were found in $15 \%$ of the profiles in spring and $37 \%$ of the profiles in summer, respectively. Convective conditions generally are observed more frequently during summer in $\mathrm{Ny}$-Ålesund related to the different level of radiation energy at disposal and surface properties. In summer, homogenous profiles were observed often (37\%) than in spring $(15 \%)$, due to a synergy of the higher solar power density at disposal $\left(186.4 \pm 71.2 \mathrm{~W} \mathrm{~m}^{-2}\right.$ in summer and $109.2 \pm 35.9 \mathrm{~W} \mathrm{~m}^{-2}$ in spring) together with a lower albedo $(0.15 \pm 0.01$ in summer and $0.87 \pm 0.04$ in spring $)$ induced by the summer snowmelt in Svalbard (Mazzola et al., 2016b). The resulting change in surface energy balance affects the atmospheric stability, from the more stable conditions and inversion situations with snow cover to the unstable conditions favoring mixing within the boundary layer once the snow cover has disappeared.

In spring, the presence of different layers of aerosol, separated by abrupt changes in the aerosol properties (i.e., concentration) along height were observed more frequently than the homogeneous mixing conditions (Fig. $2 b-d$ ). The presence of aerosol stratification was complementary to the homogenous profiles and thus occurred for 85 and $63 \%$ of cases during spring and summer, respectively.

Within stratified conditions it was possible to determine the $\mathrm{AS}_{\mathrm{h}}$ for each aerosol size and season together with the altitude of sharp changes observed also for $\theta$ and RH. For example, Fig. $2 \mathrm{c}$ shows $\mathrm{AS}_{\mathrm{h}}$ at $630 \mathrm{~m}$ in agreement with the vertical gradients of $\theta$ and RH. On the other hand, Fig. $2 \mathrm{~d}$ shows a first $\mathrm{AS}_{\mathrm{h}}$ at $134 \mathrm{~m}$ only for $N_{14-260}$, while $N_{260-1200}$ appeared homogenously distributed until a second $\mathrm{AS}_{\mathrm{h}}$ was located at $674 \mathrm{~m}$. The first $\mathrm{AS}_{\mathrm{h}}$, detected for the smallest particles, was related to a ground-based $\theta$ inversion, while the second $\mathrm{AS}_{\mathrm{h}}$, detected for the accumulation-mode particles, was related to an elevated $\theta$ inversion.

The aforementioned case studies helped us to introduce the description of the $\mathrm{AS}_{\mathrm{h}}$ frequency distribution with altitude and season. The $\mathrm{AS}_{\mathrm{h}}$ were used independently from the sign of the aerosol concentration change (either positive or negative; Fig. 2b-c) and were computed separately for each broad size range (i.e., Fig. 2d). The resulting frequency distribution with altitude of the first $\mathrm{AS}_{\mathrm{h}}$ is reported in Fig. 3a-d and $\mathrm{e}-\mathrm{h}$ for spring and summer, respectively. It has to be underlined that sometimes it was possible to detect up to two $\mathrm{AS}_{\mathrm{h}}$ for each profile. This situation was observed for $\sim 30 \%$ of profiles (characterized by the presence of aerosol gradients) in spring and summer, due to the limited maximum altitude reached by the balloon during the flight (usually between 0.7 and $1.3 \mathrm{~km}$ ). The behavior of the second $\mathrm{AS}_{\mathrm{h}}$ is shown in the Supplement (Fig. S4) to support the description of the behavior of the first aerosol stratification with altitude.

Focusing on each season and considering first the springtime $\mathrm{AS}_{\mathrm{h}}$ vertical frequency distributions (Fig. 3a-d) a common behavior can be first observed for both the three size ranges $\left(N_{14-260}, N_{260-1200}\right.$ and $\left.N_{>1200}\right)$ and meteorological parameters $(\theta$ and $\mathrm{RH})$ : all of them showed a bimodal distribution characterized by a minimum within the $\sim 400-500 \mathrm{~m}$ height range. Maturilli and Kayser (2016) identified a frequent occurrence of a temperature inversion layer in the shear zone above the mountain ridges; this phenomenon is typically present throughout the year, leading to a decoupling of the lowermost kilometer of the atmosphere from the free troposphere above. In between the mountains, the atmosphere is characterized by wind channeling along the fjord axis, disturbed by, e.g., glacier outflow or land-sea breeze. Thus, the observed separation of $\mathrm{AS}_{\mathrm{h}}$ most likely relates to the separation of the atmospheric flow.

Moving forward, some differences were then found in the behavior of each aerosol size range below and above the minimum at $400-500 \mathrm{~m}$. While $N_{260-1200}$ and $N_{>1200}$ (Fig. 3bc) appeared equally distributed below and above the minimum at $400-500 \mathrm{~m}, N_{14-260}$ showed highest frequencies of $\mathrm{AS}_{\mathrm{h}}$ below $400 \mathrm{~m}$ (Fig. 3a). Particularly, the $82 \%$ of $\mathrm{AS}_{\mathrm{h}}$ for $N_{14-260}$ were located below $400 \mathrm{~m}$ and showed a clear maximum peak close to the ground $(0-100 \mathrm{~m})$ with a frequency of 

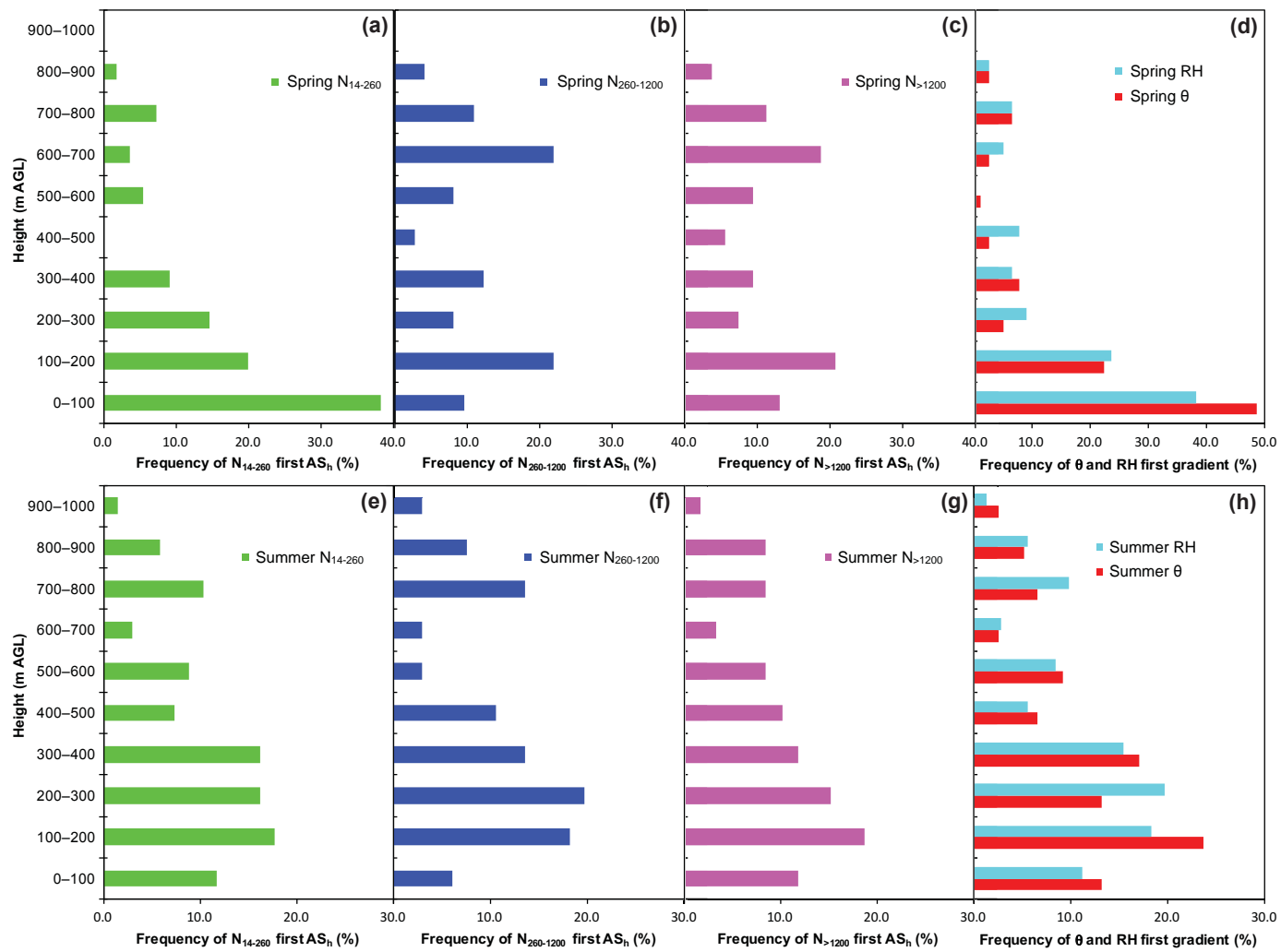

Figure 3. Vertical frequency distribution of the $\mathrm{AS}_{\mathrm{h}}$ for $N_{14-260}, N_{260-1200}, N_{>1200}, \theta$ and $\mathrm{RH}$ during spring in panels from (a) to (d) and in summer in panels from (e) to (h).

$38 \%$. Moreover, the average values of $\mathrm{AS}_{\mathrm{h}}$ for $N_{14-260}$ below and above the minimum at $400-500 \mathrm{~m}$ were $143 \pm 13 \mathrm{~m}$ and $669 \pm 32 \mathrm{~m}$, respectively. Conversely, $\mathrm{AS}_{\mathrm{h}}$ for $N_{260-1200}$ and $N_{>1200}$ occurred for 52 and $51 \%$ below $400 \mathrm{~m}$ peaking in the 100-200 $\mathrm{m}$ range ( 22 and $21 \%$, respectively) with average values of $208 \pm 19 \mathrm{~m}$ and $177 \pm 14 \mathrm{~m}$, respectively. Above $400 \mathrm{~m}$ the $\mathrm{AS}_{\mathrm{h}}$ for $N_{260-1200}$ and $N_{>1200}$ peaked in the $600-700 \mathrm{~m}$ range (22 and $19 \%$, respectively) with average values of $672 \pm 16$ and $652 \pm 20 \mathrm{~m}$.

The observed lack of symmetry between $N_{14-260}$ and $N_{260-1200}-N_{>1200}$ is explained in Fig. 2d, where a decoupled trend for $N_{14-260}$ and $N_{260-1200}$ is shown. As stated above, the behavior of smallest particles was in that case related to a ground-based $\theta$ inversion. Considering the whole data set, the behavior of the vertical frequency distribution of the first gradient of both $\theta$ and RH was in agreement with that of $\mathrm{AS}_{\mathrm{h}}$ for $N_{14-260}$. In this respect, a maximum peak for both $\theta$ and RH was found close to the ground $(0-100 \mathrm{~m})$, with a frequency of 49 and $38 \%$, respectively (average values below the minimum at $400-500 \mathrm{~m}$ for gradients for $\theta$ and $\mathrm{RH}$ of $117 \pm 12$ and $669 \pm 32 \mathrm{~m}$ ). Interestingly, the frequency of ground-based $\theta$ inversions (49\%) was higher than that of $\mathrm{AS}_{\mathrm{h}}$ for $N_{14-260}(38 \%)$. This feature is due to the vertical profile along which, even in the presence of a ground-based $\theta$ inversion, $N_{14-260}$ did not show any variation of concen- tration; an example is reported in Fig. 2b. Thus, the presence of a ground-based $\theta$ inversion appears as a necessary but not sufficient condition to observe the aforementioned behavior (resumed by Figs. 2d, 3a and d). The phenomenology and the aerosol dynamic responsible of this behavior (together with that of $N_{260-1200}-N_{>1200}$ ) will be addressed and discussed in the following Sect. 3.3.

We describe below the summer $\mathrm{AS}_{\mathrm{h}}$ behavior. Figure 3eh (and Fig. S4) show that even in summer, the multilayered structure persisted and was also characterized by a bimodal distribution, as in spring, but with a higher minimum (than in spring) that ranged approximately between 500 and $600 \mathrm{~m}$. The summer $\mathrm{AS}_{\mathrm{h}}$ for all size ranges and the gradient for $\theta$ and RH peaked between 100 and $300 \mathrm{~m}: 78 \%\left(N_{14-260}\right.$; average value $276 \pm 19 \mathrm{~m}), 71 \%\left(N_{260-1200}\right.$; average value $269 \pm 18 \mathrm{~m}), 76 \%\left(N_{>1200}\right.$; average value $\left.272 \pm 18 \mathrm{~m}\right), 83 \%$ $(\theta$; average value $262 \pm 18 \mathrm{~m})$ and $79 \%(\mathrm{RH}$; average value $268 \pm 18 \mathrm{~m}$ ). Figure $3 \mathrm{e}-\mathrm{h}$ and the aforementioned data highlight that the vertical frequency distribution for $\mathrm{AS}_{\mathrm{h}}$ of all sizes and gradients for $\theta$ and RH behave similarly. This phenomenon, different from that observed in spring, will be addressed and discussed in Sect. 3.3. As a final conclusion, a multilayered structure was found over Ny-Ålesund both in spring and summer (see also Fig. S4), and the most important atmospheric thermodynamic parameters $(\theta$ and $\mathrm{RH})$ in- 

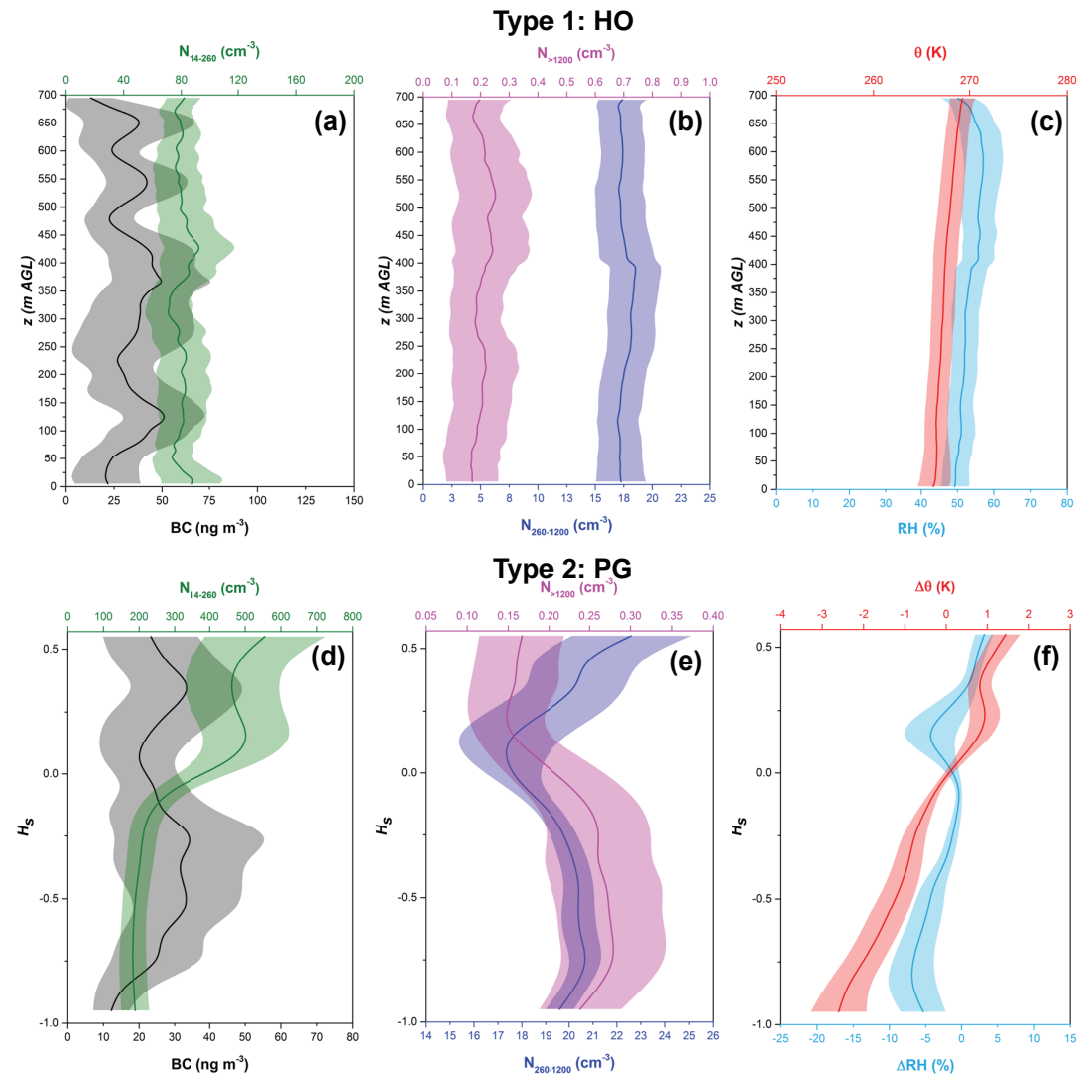

Type 3: NG
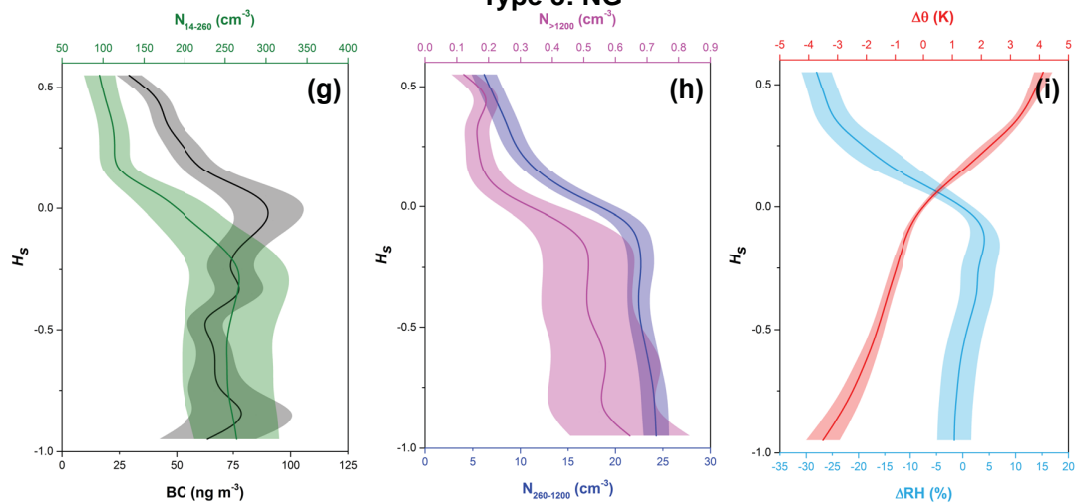

Type 4: DNG
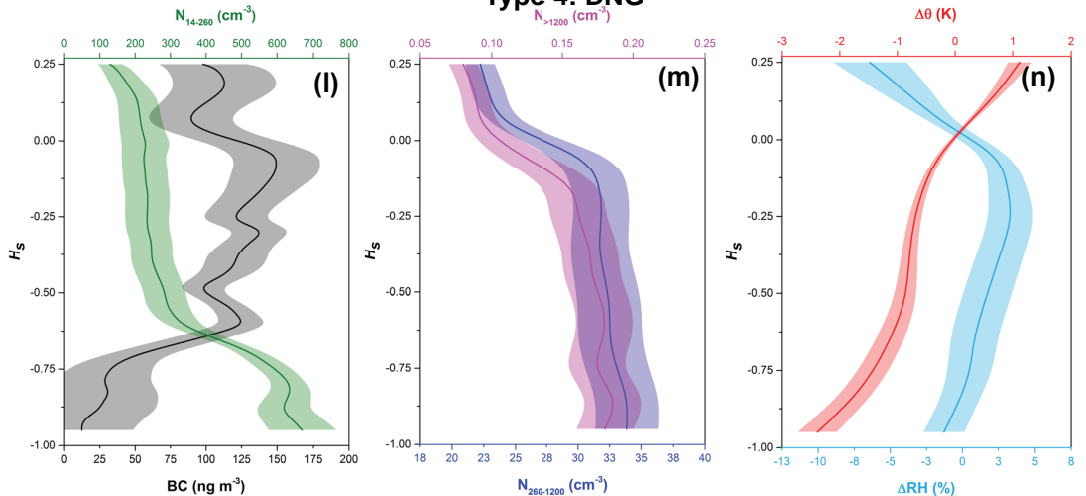

Figure 4. Springtime statistical mean profiles of $N_{14-260}$ (green line), BC (black line), $N_{260-1200}$ (blue line), $N_{>1200}$ (magenta line), $\theta$ (red line) and RH (light blue line) along height over Ny-Ålesund for the four typologies of vertical profiles: (a)-(c) homogeneous profiles (HO); (d)-(f) positive gradient profiles (PG); (g)-(i) negative gradient profiles (NG); (I)-(n) decoupled negative gradient profiles (DNG). 
dicated the role of meteorology in shaping the aerosol vertical profiles. This result is of great importance as the majority of the aerosol measurements conducted in the Arctic area are ground based and thus, it is necessary to understand their validity with altitude.

\subsection{Springtime phenomenology}

The previous section introduced the vertical behavior of sized aerosol in terms of frequency distribution of $\mathrm{AS}_{\mathrm{h}}$. However, it is also necessary to describe the intensity of the aerosol concentration changes at the $\mathrm{AS}_{\mathrm{h}}$ and the possible dynamics underlying these changes. Thus, in this section, the springtime vertical aerosol phenomenology will be investigated. All the profiles measured in spring 2011 were classified based on their vertical behavior (i.e., shape) and averaged considering the relative position of each measured data point with respect to the $\mathrm{AS}_{\mathrm{h}}$. The obtained averaged vertical profiles were referred to a standardized height $\left(H_{\mathrm{s}}\right.$; Eq. 12$)$ as described in Sect. 2.2.3. As the size classes can behave differently with height, $H_{\mathrm{s}}=0$ was referred to that observed for the intermediate $N_{260-1200}$ size class. The result of the classification and averaging procedure is reported in Fig. 4a-n (all profile data are reported in Fig. S5). Four main typologies of vertical profile were found. According to their shape they were named as follows:

1. Type 1, homogeneous profiles (hereinafter referred to as HO), Fig. 4a-c;

2. Type 2, profiles characterized by a positive gradient at $H_{\mathrm{s}}=0$ (hereinafter referred to as PG), Fig. 4d-f;

3. Type 3, profiles characterized by a negative gradient at $H_{\mathrm{s}}=0$ (hereinafter referred to as NG), Fig. $4 \mathrm{~g}-\mathrm{i}$;

4. Type 4, profiles characterized by negative gradients located at different altitude as a function of size (hereinafter referred to as decoupled negative gradient, DNG), Fig. 41-n.

Average concentrations of aerosol $\left(N_{14-260}, N_{260-1200}\right.$, $\left.N_{>1200}\right)$ and eBC below and above $H_{\mathrm{s}}=0$ for each profile class are summarized in Table 3.

We first report here the columnar averages of both total aerosol number and eBC concentrations obtained by averaging all the aforementioned profile classes: $236.1 \pm 23.9 \mathrm{~cm}^{-3}\left(N_{14-260}\right), 21.1 \pm 1.3 \mathrm{~cm}^{-3}\left(N_{260-1200}\right)$, $0.2 \pm 4 \times 10^{-2} \mathrm{~cm}^{-3}\left(N_{>1200}\right)$ and $52 \pm 8 \mathrm{ng} \mathrm{m}^{-3}(\mathrm{eBC})$. They perfectly agree with long-term data series collected over Ny-Ålesund at the Zeppelin observatory (Eleftheriadis et al., 2009; Tunved et al., 2013) during spring ( 100$250 \mathrm{~cm}^{-3}$ and $50-70 \mathrm{ng} \mathrm{m}^{-3}$ of eBC during April). This agreement indicates that all the profile classes discussed below can be considered characteristic (with their occurring frequencies and altitudes) for the background Arctic aerosols measured by Arctic observatories within GAW, AMAP and
EMEP observation programs. Moreover, the eBC data also agreed with results from PAM-ARCMIP (Stone et al., 2010) which showed a $40-90 \mathrm{ng} \mathrm{m}^{-3}$ range of $\mathrm{eBC}$ within the surface inversion layer and $30-50 \mathrm{ng} \mathrm{m}^{-3}$ above.

All the CCT wind data were used to compute wind rose graphs timely coincident with each profile typology (Fig. 5ad) and will be used in the following sections. The fjord direction into which the wind is often channeled is NW-SE. Here, we underline that Fig. 5a-d show the absence of wind from the north during the profile measurements; thus, any influence from the Ny-Ålesund village is negligible. In addition, Fig. 6 shows the ground-based number size distribution measured at Gruvebadet (Sect. 2.1) for HO, PG, NG and DNG profiles, respectively.

Finally, a brief discussion of the air masses' origin for the four categories is summarized in the Supplement (see also Fig. S6).

\subsubsection{Homogeneous (HO) profiles}

HO profiles (Type 1; Fig. 4a-c) were observed in $15 \%$ of cases (for 7 days) and were characterized by a homogenous vertical distribution of aerosol and eBC upon Ny-Ålesund. HO profiles are reported with an absolute height AGL, because they did not show any $\mathrm{AS}_{\mathrm{h}}$ to calculate $H_{\mathrm{s}}$. They appear in some way analogous to the relatively diffuse background aerosol reported in the springtime ARCPAC campaign (Brock et al., 2011). During HO profiles, local wind (Fig. 5a) was blowing mainly from the SW direction, from the glaciers behind Ny-Ålesund (Fig. 1a) and not along the predominant NW-SE direction. Moreover, HO profiles featured the lowest wind speed (range $0-2 \mathrm{~m} \mathrm{~s}^{-1}$, average of $0.6 \pm 0.1 \mathrm{~m} \mathrm{~s}^{-1}$ at $33 \mathrm{~m}$; Table 2).

At the same time, as shown in Fig. $4 \mathrm{c}$, slightly positive $\theta$ profiles characterized, on average, the HO profiles. Profiles of $\theta$ with both positive and negative vertical gradients (as shown in Fig. 2a) contributed to this average. Negative $\theta$ gradients allowed vertical mixing. Positive $\theta$ gradients instead favored stable conditions. However, they do not contrast the absence of an aerosol stratification. In fact, just the presence of an important aerosol source (either local or transported) allow the formation of a distinct aerosol layer. This process is detailed in Sect. 3.2.3.

The number concentrations in $\mathrm{HO}$ profiles were $80.2 \pm 16.4 \mathrm{~cm}^{-3} \quad(81.9 \pm 16.8 \%$ of the total aerosol concentration), $17.5 \pm 2.0 \mathrm{~cm}^{-3}(17.9 \pm 2.0 \%$ of the total aerosol concentration) and $0.2 \pm 0.1 \mathrm{~cm}^{-3}(0.2 \pm 0.1 \%$ of the total aerosol concentration) for $N_{14-260}, N_{260-1200}$ and $N_{>1200}$, respectively. The aerosol number concentration was thus dominated by the $N_{14-260}$ size fraction along the whole profile. eBC and the related $b_{\text {abs }}$ (Sect. 2.2.2; Eq. 4) reached values of $35 \pm 21 \mathrm{ng} \mathrm{m}^{-3}$ and $0.22 \pm 0.13 \mathrm{Mm}^{-1}$.

Aerosol number concentration in $\mathrm{HO}$ profiles lies close to the lower values registered at Zeppelin in April (Tunved et al., 2013) and were characterized by a ground-based size 
Table 2. Meteorological parameters (temperature, relative humidity, wind speed, pressure) measured at the CCT at different levels ( $33,10,5$ and $2 \mathrm{~m}$ ) and averaged (timely coincident) for each profile class.

\begin{tabular}{|c|c|c|c|c|c|c|c|c|c|c|c|c|c|c|c|}
\hline \multirow[t]{2}{*}{ Season } & \multicolumn{2}{|c|}{ Profile type } & \multicolumn{4}{|c|}{$\mathrm{T}\left({ }^{\circ} \mathrm{C}\right)$} & \multicolumn{4}{|c|}{ RH (\%) } & \multicolumn{4}{|c|}{$\mathrm{WS}\left(\mathrm{m} \mathrm{s}^{-1}\right)$} & \multirow{2}{*}{$\begin{array}{l}\mathrm{P}(\mathrm{hPa}) \\
\text { Ground }\end{array}$} \\
\hline & & & $33 \mathrm{~m}$ & $10 \mathrm{~m}$ & $5 \mathrm{~m}$ & $2 \mathrm{~m}$ & $33 \mathrm{~m}$ & $10 \mathrm{~m}$ & $5 \mathrm{~m}$ & $2 \mathrm{~m}$ & $33 \mathrm{~m}$ & $10 \mathrm{~m}$ & $5 \mathrm{~m}$ & $2 \mathrm{~m}$ & \\
\hline \multirow[t]{8}{*}{ Spring } & $\mathrm{HO}$ & mean & -8.5 & -8.9 & -9.7 & -9.7 & 61.0 & 61.2 & 61.8 & 62.7 & 0.6 & 0.7 & 0.6 & 0.6 & 997.4 \\
\hline & & $\sigma_{\mathrm{m}}$ & 0.5 & 0.5 & 0.5 & 0.5 & 1.0 & 1.0 & 0.9 & 0.9 & 0.1 & 0.1 & 0.1 & 0.1 & 0.4 \\
\hline & PG & mean & -4.7 & -5.2 & -5.8 & -5.9 & 64.8 & 65.0 & 65.9 & 67.3 & 2.3 & 2.1 & 1.8 & 1.7 & 996.2 \\
\hline & & $\sigma_{\mathrm{m}}$ & 0.2 & 0.3 & 0.3 & 0.3 & 0.4 & 0.4 & 0.4 & 0.4 & 0.1 & 0.1 & 0.1 & 0.1 & 0.5 \\
\hline & NG & mean & -8.9 & -9.3 & -9.9 & -9.9 & 57.2 & 58.5 & 59.1 & 60.1 & 1.3 & 1.1 & 1.0 & 0.9 & 992.8 \\
\hline & & $\sigma_{\mathrm{m}}$ & 0.2 & 0.2 & 0.2 & 0.2 & 0.4 & 0.3 & 0.3 & 0.3 & 0.1 & 0.1 & 0.1 & 0.1 & 0.2 \\
\hline & DNG & mean & -15.8 & -16.5 & -17.2 & -17.2 & 72.6 & 73.2 & 72.9 & 73.6 & 0.7 & 0.9 & 1.0 & 0.9 & 994.8 \\
\hline & & $\sigma_{\mathrm{m}}$ & 0.3 & 0.3 & 0.3 & 0.3 & 0.5 & 0.3 & 0.3 & 0.3 & 0.1 & 0.1 & 0.1 & 0.1 & 0.4 \\
\hline \multirow[t]{4}{*}{ Summer } & $\mathrm{HO}$ & mean & 5.7 & 5.8 & 5.5 & 6.0 & 76.5 & 75.3 & 74.7 & 74.9 & 4.1 & 3.8 & 3.6 & 3.4 & 1004.1 \\
\hline & & $\sigma_{\mathrm{m}}$ & 0.1 & 0.1 & 0.1 & 0.1 & 0.2 & 0.2 & 0.2 & 0.2 & 0.1 & 0.1 & 0.1 & 0.1 & 0.2 \\
\hline & SP & mean & 5.8 & 5.9 & 5.6 & 6.1 & 78.0 & 76.4 & 75.6 & 75.8 & 2.6 & 2.6 & 2.5 & 2.4 & 1001.9 \\
\hline & & $\sigma_{\mathrm{m}}$ & 0.1 & 0.1 & 0.1 & 0.1 & 0.2 & 0.2 & 0.2 & 0.2 & 0.1 & 0.1 & 0.1 & 0.1 & 0.1 \\
\hline
\end{tabular}

Table 3. Average concentrations of $N_{14-260}, N_{260-1200}, N_{>1200}$, eBC and $b_{\text {abs }}$ along height over Ny-Ålesund for the springtime and summertime typologies of vertical profiles.

\begin{tabular}{|c|c|c|c|c|c|c|c|}
\hline Season & Profile type & & $N_{14-260}\left(\mathrm{~cm}^{-3}\right)$ & $N_{260-1200}\left(\mathrm{~cm}^{-3}\right)$ & $N_{>1200}\left(\mathrm{~cm}^{-3}\right)$ & $\mathrm{eBC}\left(\mathrm{ng} \mathrm{m}^{-3}\right)$ & $b_{\text {abs }}\left(\mathrm{Mm}^{-1}\right)$ \\
\hline \multirow[t]{16}{*}{ Spring } & \multirow[t]{2}{*}{ HO (column) } & mean & 80.2 & 17.5 & 0.20 & 35 & 0.22 \\
\hline & & $\sigma_{\mathrm{m}}$ & 16.4 & 2 & 0.10 & 21 & 0.13 \\
\hline & \multirow[t]{2}{*}{ PG $(\mathrm{Hs}<0)$} & mean & 205.4 & 19.9 & 0.26 & 24 & 0.14 \\
\hline & & $\sigma_{\mathrm{m}}$ & 12.5 & 0.2 & 0.02 & 3 & 0.02 \\
\hline & \multirow[t]{2}{*}{ PG $(\mathrm{Hs}>0)$} & mean & 557.6 & 22.3 & 0.16 & 26 & 0.16 \\
\hline & & $\sigma_{\mathrm{m}}$ & 45.9 & 1.4 & 0.02 & 4 & 0.02 \\
\hline & \multirow[t]{2}{*}{ NG (Hs textless 0$)$} & mean & 252.3 & 23.1 & 0.53 & 71 & 0.43 \\
\hline & & $\sigma_{\mathrm{m}}$ & 17.5 & 0.4 & 0.05 & 4 & 0.02 \\
\hline & \multirow[t]{2}{*}{ NG $(\mathrm{Hs}>0)$} & mean & 118.9 & 9.7 & 0.18 & 39 & 0.24 \\
\hline & & $\sigma_{\mathrm{m}}$ & 9.3 & 0.3 & 0.02 & 2 & 0.01 \\
\hline & \multirow[t]{2}{*}{ DNG (Hs $<0$, ground Aitken plume) } & mean & 601.3 & 32.4 & 0.17 & 36 & 0.22 \\
\hline & & $\sigma_{\mathrm{m}}$ & 19.9 & 0.8 & 0.01 & 11 & 0.06 \\
\hline & \multirow[t]{2}{*}{ DNG (Hs <0, above-ground plume) } & mean & 260.6 & 32.4 & 0.17 & 121 & 0.74 \\
\hline & & $\sigma_{\mathrm{m}}$ & 13.1 & 0.8 & 0.01 & 5 & 0.03 \\
\hline & \multirow[t]{2}{*}{ DNG $(\mathrm{Hs}>0)$} & mean & 187.8 & 22.3 & 0.08 & 102 & 0.62 \\
\hline & & $\sigma_{\mathrm{m}}$ & 17.8 & 0.5 & 0.01 & 11 & 0.07 \\
\hline \multirow[t]{6}{*}{ Summer } & \multirow[t]{2}{*}{ HO (column) } & mean & 435.9 & 2.1 & 0.04 & - & - \\
\hline & & $\sigma_{\mathrm{m}}$ & 5.8 & 0.1 & 0.004 & - & - \\
\hline & \multirow[t]{2}{*}{$\mathrm{SP}(\mathrm{Hs}<0)$} & mean & 9000 & 7.0 & 0.06 & 319 & 1.95 \\
\hline & & $\sigma_{\mathrm{m}}$ & 250 & 0.7 & 0.004 & 14 & 0.09 \\
\hline & \multirow{2}{*}{$\mathrm{SP}(\mathrm{Hs}>0)$} & mean & 648.1 & 1.4 & 0.01 & 24 & 0.15 \\
\hline & & $\sigma_{\mathrm{m}}$ & 27.3 & 0.1 & 0.001 & 1 & 0.01 \\
\hline
\end{tabular}

distribution dominated by the accumulation-mode particles (Fig. 6). eBC was close to the 25-50th percentiles reported in Eleftheriadis et al. (2009) for April and to the lower troposphere value of refractory $\mathrm{BC}(\mathrm{rBC})$ measured in spring during the HIPPO campaign (Schwarz et al., 2013).

Within HO profiles, the aerosol pollution, previously transported from midlatitudes, affected the first kilometer of the atmosphere. The observed homogenous mixing conditions allowed us to assume that the aerosol properties measured at ground level in $\mathrm{Ny}-\AA$ Alesund were representative of the lower troposphere.

\subsubsection{Positive gradient (PG) profiles}

PG profiles (Type 2; Fig. 4d-f) occurred in $17 \%$ of cases (for 6 days) and were characterized by an increase of aerosol number concentrations above $H_{\mathrm{s}}=0$ and moderate eBC concentrations $\left(24 \pm 3 \mathrm{ng} \mathrm{m}^{-3} ; b_{\text {abs }}\right.$ was $\left.0.15 \pm 0.02 \mathrm{Mm}^{-1}\right)$. The average value of $\mathrm{AS}_{\mathrm{h}}$ (corresponding to $H_{\mathrm{s}}=0$ ) was $417 \pm 266 \mathrm{~m}$. During PG profiles, local wind (Fig. 5b) was blowing mainly from the SE along the predominant NW-SE direction. This situation is common in Kongsfjorden (Vihma et al., 2011). PG profiles featured the highest wind speed (range $0-5 \mathrm{~m} \mathrm{~s}^{-1}$, average of $2.3 \pm 0.1 \mathrm{~m} \mathrm{~s}^{-1}$ at $33 \mathrm{~m}$; Ta- 

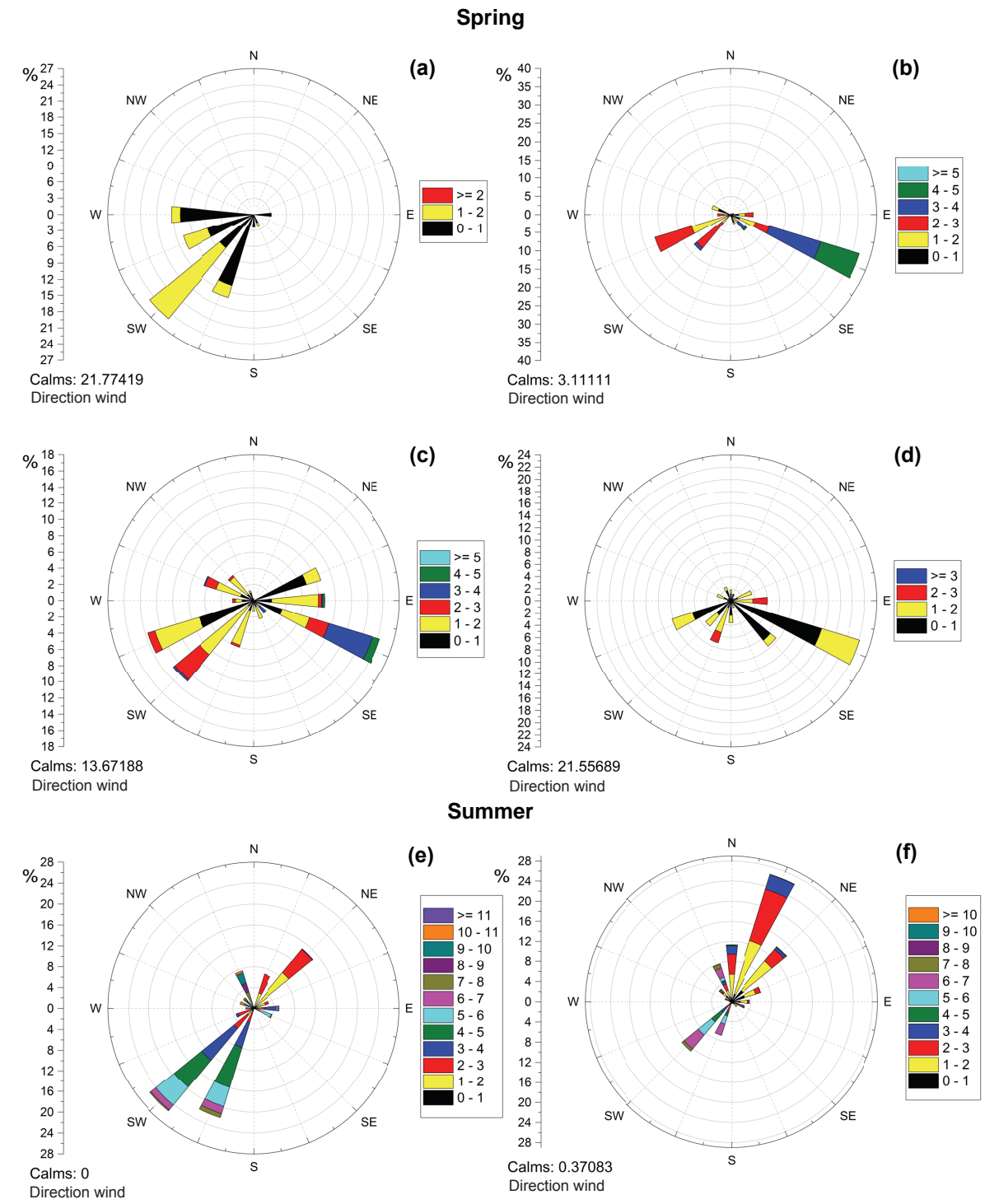

Figure 5. Wind rose obtained from the measured wind speed and direction at the CCT (33 m). Springtime wind rose timely coincident with (a) homogeneous profiles (HO); (b) positive gradient profiles (PG); (c) negative gradient profiles (NG); (d) decoupled negative gradient profiles (DNG). Summertime wind rose timely coincident with (e) homogeneous profiles (HO); (f) profiles impacted by shipping emissions (SP).

ble 2). At the same time, as shown in Fig. 4f, a positive $\theta$ profile was present with $\mathrm{a}+1.5 \pm 0.4 \mathrm{~K}$ increase from $H_{\mathrm{s}}=0$. A stable atmosphere was present and the aerosol was brought to the site by long-range transport in this stable situation. The increment of aerosol number concentrations with altitude was particularly evident for $N_{14-260}$ that increased by $+171.5 \pm 25.4 \%$ (going from $205.4 \pm 12.5 \mathrm{~cm}^{-3}$ below the $\mathrm{AS}_{\mathrm{h}}$ to $557.6 \pm 45.9 \mathrm{~cm}^{-3}$ above it) while $N_{260-1200}$ experienced a more modest increase of $11.8 \pm 7.0 \%$ (going from $19.9 \pm 0.2 \mathrm{~cm}^{-3}$ below the $\mathrm{AS}_{\mathrm{h}}$ to $22.3 \pm 1.4 \mathrm{~cm}^{-3}$ above it). Conversely, the coarse fraction $\left(N_{>1200}\right)$ decreased with altitude of $-38.1 \pm 10.0 \%$ (going from $0.26 \pm 0.02 \mathrm{~cm}^{-3}$ below the $\mathrm{AS}_{\mathrm{h}}$ to $0.16 \pm 0.02 \mathrm{~cm}^{-3}$ above it). The observed increase of Aitken and accumulation-mode fractions $\left(N_{14-260}\right.$ plus $N_{260-1200}$ ), and the corresponding decrease of the coarse fraction $\left(N_{>1200}\right)$ appear to be in agreement with the observation that during transport events wet removal processes and dry deposition decrease the coarse particle concentration by scavenging and, at the same time, establish conditions that favor secondary aerosol formation due to the lowering of the condensational sink (Tunved et al., 2013).

The aerosol number concentration values above $H_{\mathrm{s}}=0$ were close to those reported in Engvall et al. (2008b) for the Arctic free troposphere during ASTAR. The ground-based size distribution, not influenced by the pollution layer at high 


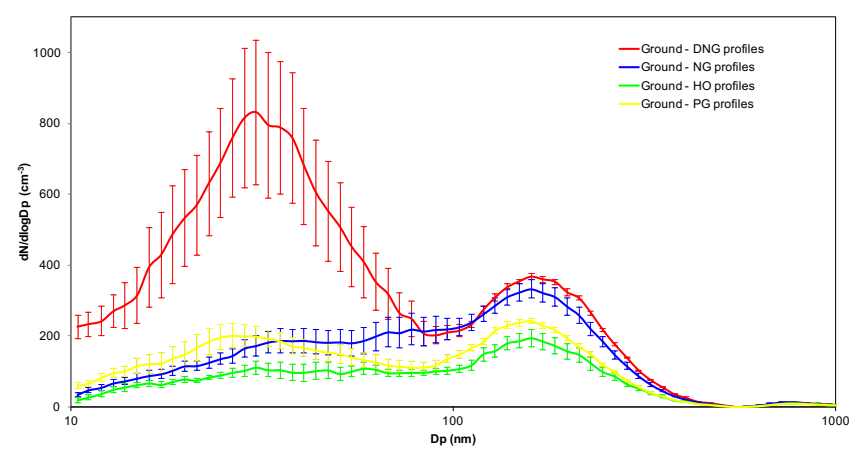

Figure 6. Springtime aerosol number size distribution measured at ground and timely coincident with homogeneous profiles (HO), positive gradient profiles (PG), negative gradient profiles (NG) and decoupled negative gradient profiles (DNG).

altitude, was dominated by accumulation-mode particles as in HO profiles (Fig. 6).

The PG profile data suggested that high-altitude transport events could be the origin of these types of profiles during springtime. An example of this process is the interesting case study of 23 April 2011 (12:00-13:30 UTC), when an intense plume of aerosol was transported over $\mathrm{Ny}$-Ålesund. Figure $7 \mathrm{a}-\mathrm{b}$ show this event with the associated air mass back trajectories, and the time evolution of the event obtained through the interpolation of six vertical profiles, each of which lasted $\sim 15 \mathrm{~min}$ and was removed about $1 \mathrm{~min}$ from the following profile.

Altitude layers of pollution were documented in Brock et al. (2011) and in Kupiszewski et al. (2013) and Wofsy et al. (2011). Jacob et al. (2010) reported that transport from North America and east Asia takes place mainly at higher altitudes, as also documented in Stohl et al. (2006). In this respect, the back-trajectories reported in Fig. 7a described high altitude air from North America and Asia that descended in the Arctic. High aerosol concentrations at high altitude are important because aerosols can act as $\mathrm{CCN}$ and thus impact on climate via the indirect aerosol effects.

\subsubsection{Negative gradient (NG) profiles}

NG profiles (Fig. $4 \mathrm{~g}-\mathrm{i}$ ) were observed in $48 \%$ of all cases (for 9 days) making the NG the dominant typology of profiles. The average value of $\mathrm{AS}_{\mathrm{h}}$ (corresponding to $H_{\mathrm{s}}=0$ ) was $506 \pm 212 \mathrm{~m}$. The predominant wind direction was the same as in PG profiles (SE-E direction) with a component also from SW (Fig. 5c). Figure 4i shows that a strong, positive $\theta$ profile $\left(+4.1 \pm 0.3 \mathrm{~K}\right.$ increase from $\left.H_{\mathrm{s}}=0\right)$ characterized NG profiles.

Within this condition, the case study reported in Fig. 7b showed the origin of NG profiles. Figure $7 \mathrm{~b}$ shows first a transport event that generated PG profiles (Sect. 3.2.2). Afterwards, the transported aerosol was mixed downward within the PBL until ground. Most important, at the end of the pro- cess (13:30 UTC) a negative concentration gradient with altitude was established generating a NG profile.

As now shown, NG profiles might have originated from the entrance of Arctic haze into the PBL after a transport process. In the Arctic, in absence of an important local aerosol source (i.e., nucleation which acts mainly in summer; Tunved et al., 2013), only transported aerosol trapped within a thermal inversion made possible the presence of this typology of profiles. The presence of an intense $\theta$ inversion stabilizes the situation maintaining a NG typology of profile since vertical mixing is prevented (see also Fig. 2c). It has to be noticed that an intense $\theta$ inversion is just a necessary condition to promote the formation of NG profiles, not a sufficient one. This result explains the presence of $\mathrm{HO}$ profiles even in a stable atmosphere (Sect. 3.2.1) and is in agreement with the observation (reported in Sect. 3.1.1) that the frequency of groundbased $\theta$ inversions (49\%; Fig. 3d) reached values higher than those for any $\mathrm{AS}_{\mathrm{h}}$ for any aerosol size (Fig. 3a-c).

NG profiles were characterized by high pollution levels below $H_{\mathrm{s}}=0$ where an intense decrease of both aerosol and eBC was observed. Crossing the $\mathrm{AS}_{\mathrm{h}}$, aerosol concentrations decreased by $-52.9 \pm 8.7 \%$ (from $252.3 \pm 17.5$ to $118.9 \pm 9.3 \mathrm{~cm}^{-3}$ ) for $N_{14-260}$, by $-57.9 \pm 2.6 \%$ (from $23.1 \pm 0.4$ to $9.7 \pm 0.3 \mathrm{~cm}^{-3}$ ) for $N_{260-1200}$ and by $-66.5 \pm 11.5 \%$ (from $0.53 \pm 0.05$ to $0.18 \pm 0.02 \mathrm{~cm}^{-3}$ ) for $N_{>1200}$. eBC behaved similarly, decreasing by $-50.4 \pm 6.8 \%$ (from $71 \pm 4$ to $35 \pm 2 \mathrm{ng} \mathrm{m}^{-3}$ ), with the same phenomenology for $b_{\text {abs }}$ (from $0.43 \pm 0.02$ to $\left.0.21 \pm 0.01 \mathrm{Mm}^{-1}\right)$. The last finding is very important because the altitude of eBC occurrence in the atmosphere modulates its influence on the climate in the Arctic.

NG profiles exhibited characteristics in agreement with literature data. Focusing on $\mathrm{eBC}$, the vertical behavior and the observed concentrations agreed with those found in the PAM-ARCMIP campaign. Stone et al. (2010) reported rBC concentrations of $40-90 \mathrm{ng} \mathrm{m}^{-3}$ within the surface-based temperature inversion layer, decreasing to $30-50 \mathrm{ng} \mathrm{m}^{-3}$ above it. Results reported in Schwarz et al. (2013) for the HIPPO campaign in January agree with our measurements. Aerosol number concentration and $\mathrm{eBC}$ are also close to the higher values registered at the Zeppelin station in April (Tunved et al., 2013; Eleftheriadis et al., 2009). In fact, NG profiles represent the most polluted situation affecting the whole boundary layer, quite the opposite to HO profiles.

\subsubsection{Decoupled negative gradient (DNG) profiles}

A particular kind of profiles characterized by a decrease in concentration with altitude is the DNG typology. Within this class, observed in $20 \%$ of cases (for 5 days), a lack of symmetry between $N_{14-260}$ and $N_{260-1200}-N_{>1200}$ was observed (Fig. 41-n). The average value of $\mathrm{AS}_{\mathrm{h}}$ (corresponding to $\left.H_{\mathrm{s}}=0\right)$ was $585 \pm 90 \mathrm{~m}$. The main wind direction was the same as in PG profiles (SE-E direction; Fig. 5d) but with a 
(a)

NOAA HYSPLIT MODEL

Backward trajectories ending at 1300 UTC 23 Apr 11 GDAS meteorological data

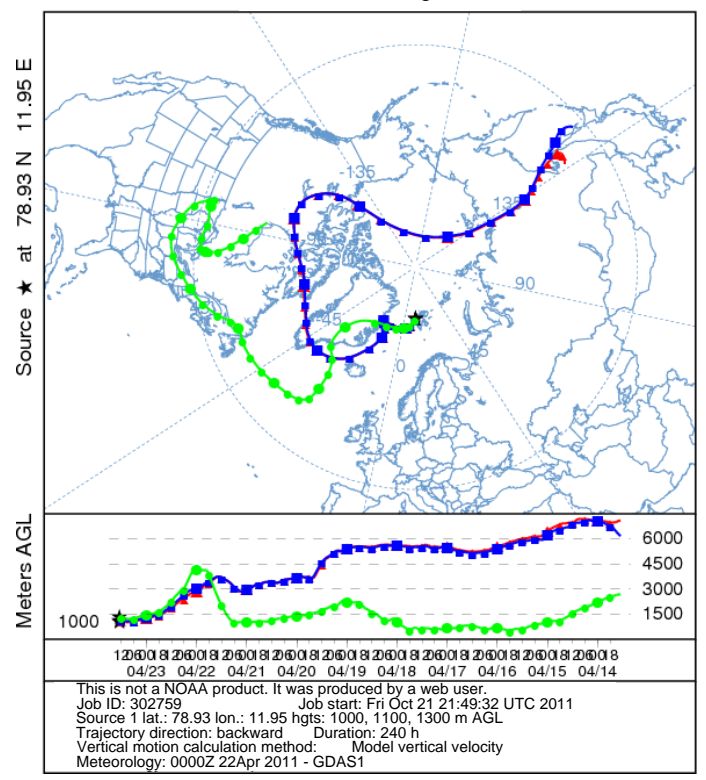

(b)

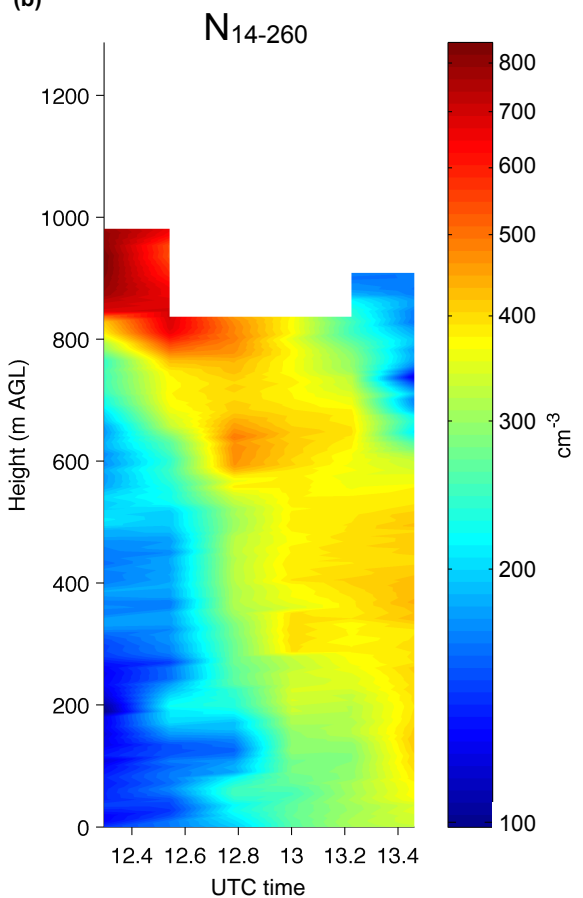

Figure 7. Case study of 23 April 2011 (12:00-13:30 UTC): (a) air mass back-trajectories; (b) time evolution of $N_{14-260}$ obtained through the interpolation of six vertical profiles, each of which lasted $\sim 15 \mathrm{~min}$ and was distanced $\sim 1 \mathrm{~min}$ from the following profile.

lower wind speed (close to that of HO profiles; $0-2 \mathrm{~m} \mathrm{~s}^{-1}$; average of $0.7 \pm 0.1 \mathrm{~m} \mathrm{~s}^{-1}$ at $33 \mathrm{~m}$ ).

Figure $4 \mathrm{n}$ shows two strong, positive $\theta$ inversions. The first one, ground based, resulted in $+1.3 \pm 0.4 \mathrm{~K}$ increase from ground; the second one characterized by $+1.1 \pm 0.2 \mathrm{~K}$ increase from $H_{\mathrm{s}}=0$.

Within this condition, $N_{14-260}$ showed a concentration peak close to the ground of $601.3 \pm 19.9 \mathrm{~cm}^{-3}$ that was not present for $N_{260-1200}$ and $N_{>1200}$. $N_{14-260}$ quickly decreased above the ground-based peak $(-56.7 \pm 4.4 \%)$ to a concentration value of $260.6 \pm 13.1 \mathrm{~cm}^{-3}$ analogous to that observed in standard NG profiles $\left(252.3 \pm 17.5 \mathrm{~cm}^{-3}\right)$ below the $\mathrm{AS}_{\mathrm{h}}$ (before reaching $H_{\mathrm{S}}=0$ ). $N_{260-1200}$ and $N_{>1200}$ instead remained quite constant $(32.4 \pm 0.8$ and $0.17 \pm 0.01 \mathrm{~cm}^{-3}$, respectively) from ground until $H_{\mathrm{s}}=0$ where they decreased by $-31.1 \pm 2.9 \%$ (to $22.3 \pm 0.8 \mathrm{~cm}^{-3}$ ) and by $-54.2 \pm 4.7 \%$ (to $0.08 \pm 0.01 \mathrm{~cm}^{-3}$ ), respectively.

Interestingly, eBC concentrations behave contrarily to the $N_{14-260}$ aerosol fraction. Lowest eBC concentrations were found close to the ground $\left(36 \pm 11 \mathrm{ng} \mathrm{m}^{-3} ; b_{\text {abs }}\right.$ was $0.22 \pm 0.06 \mathrm{Mm}^{-1}$ ) in correspondence of the $N_{14-260}$ concentration peak. Above this peak, $\mathrm{eBC}$ concentrations were higher $\left(121 \pm 5 \mathrm{ng} \mathrm{m}^{-3} ; b_{\text {abs }}\right.$ was $\left.0.74 \pm 0.03 \mathrm{Mm}^{-1}\right)$.

All the aforementioned observations suggest that a particular process could have influenced ground-level concentrations for this size class only. In order to shed light on this process, several parameters will be considered below, namely meteorological parameters, the aerosol chemical composi- tion and the aerosol number size distribution. Starting with meteorological parameters, and recalling first Fig. 2d, we see that the behavior of smallest particles in the proximity of the ground can be observed concomitantly to the presence of ground-based $\theta$ inversions, a necessary condition (or a concurrent cause) to promote the presence of ground-based concentration peaks for $N_{14-260}$. The crucial point to unravel this phenomenon is to understand the possible origin of these particles.

Thus, ground-based aerosol and meteorological measurements collected at Gruvebadet laboratory and at the CCT (Sect. 2.1), and temporally coincident with the observation of DNG profile, were considered.

Figure 8 show the ground-level $\mathrm{PM}_{10}$ chemical composition determined for the four categories ( $\mathrm{HO}, \mathrm{PG}, \mathrm{NG}, \mathrm{DNG})$ of profiles.

The nss-nc-SO $\mathrm{SO}_{4}^{2-}$ in $\mathrm{DNG}$ profiles $\left(1349.9 \pm 354.7 \mathrm{ng} \mathrm{m}^{-3}\right)$ was $3.0 \pm 0.7$ times higher than that observed in the other profile classes $(389.9 \pm 113.2$, $410.5 \pm 104.3$ and $622.1 \pm 210.0 \mathrm{ng} \mathrm{m}^{-3}$ for $\mathrm{HO}$, PG and $\mathrm{NG})$. At the same time, the $\mathrm{ss}^{-\mathrm{SO}_{4}^{2-}}$ was $0.6 \pm 0.2$ times lower compared to the other profile classes while the $\mathrm{cr}^{-} \mathrm{SO}_{4}^{2-}$ remained quite constant (ratio $1.1 \pm 0.4$ ). The same pattern can be observed considering the aforementioned sulfate fractions in the $\mathrm{PM}_{10}$ samples (Fig. S7).

These observations, coupled with the lowering of eBC fraction in proximity of the ground (Fig. 4l), point to- 


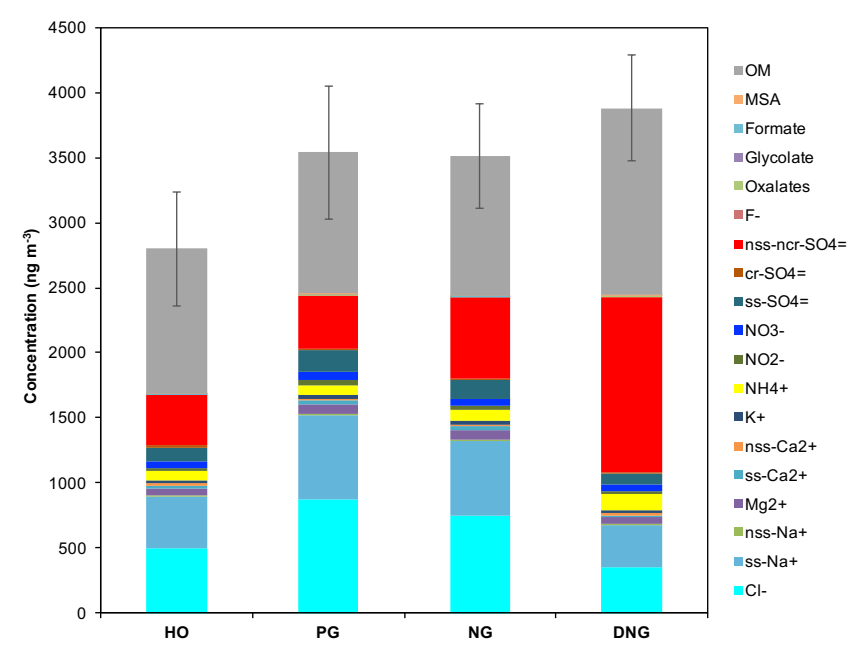

Figure 8. Springtime aerosol chemical composition determined at ground during (a) homogeneous profiles (HO); (b) positive gradient profiles (PG); (c) negative gradient profiles (NG); (d) decoupled negative gradient profiles (DNG). Data shown are the ambient concentrations of each individual aerosol species.

wards the hypothesis that the ground-based $N_{14-260}$ concentration peak was secondary in origin. The nss-nc- $\mathrm{SO}_{4}^{2-}$ fraction during DNG profiles appeared in acidic form, as it was just poorly neutralized by the ammonium. Particularly, the $w / w$ (weight/weight) nss-nc- $\mathrm{SO}_{4}^{2-} / \mathrm{NH}_{4}^{+}$ratio was $1.6 \pm 0.4$ times higher for DNG profiles $(10.3 \pm 1.5)$ than that observed in the other profile classes: $6.1 \pm 1.9$, $5.8 \pm 2.1$ and $7.0 \pm 2.2$ for $\mathrm{HO}, \mathrm{PG}$ and NG, respectively. As reported in the literature (Udisti et al., 2016; Becagli et al., 2012; Udisti et al., 2012) these values for DNG profiles feature the presence of sulfate in acidic form $\left(\mathrm{H}_{2} \mathrm{SO}_{4}\right)$. This is in agreement with the finding that "springtime submicron aerosol in the Arctic surface sites is composed predominantly of partially neutralized sulfate and sea salt, with lesser contributions from nitrate, BC, soil and trace elements" as reported in Quinn et al. (2002).

This information is very important when coupled with meteorological data measured at the CCT (Table 2). Focusing first on the air temperature, it can be observed that during DNG profiles, the temperature close to the ground $\left(-17.2 \pm 0.3^{\circ} \mathrm{C}\right)$ was lower than that observed in the other profile classes: $-9.7 \pm 0.5,-5.9 \pm 0.3$ and $-9.9 \pm 0.2$ for HO, PG and NG, respectively. In addition, the RH was $18.0 \pm 2.0 \%$ higher $(73.6 \pm 0.3 \%)$ for DNG profiles, compared to that observed in the other profile classes. Finally, the wind speed during DNG profiles was half of that during the other profile classes and was not affected by north direction, avoiding the influence of Ny-Ålesund (Fig. 5d). All the aforementioned conditions, featured during DNG profiles, can be resumed in higher acidic sulfate fraction, lower $\mathrm{eBC}$ fraction, lower temperature, higher relative humidity and lower wind speed during DNG profiles.
As reported in the literature (Kirkby et al., 2011; Reddington et al., 2011; Lovejoy, 2004) these conditions decrease the height of the barrier for new particle formation just considering the very simplified binary $\mathrm{H}_{2} \mathrm{SO}_{4}-\mathrm{H}_{2} \mathrm{O}$ system. Under these conditions, the secondary aerosol formation can proceed at ambient acid concentrations in the cooler midtroposphere and at lower altitude in polar regions. However, it has to be underlined that, as recently reported (Riccobono et al., 2014), organics plays a fundamental role for secondary aerosol formation. They were found in Ny-Ålesund even in spring (Zangrando et al., 2013). These figures, coupled with the aforementioned data indicated the $N_{14-260}$ concentration peaks at ground as locally formed secondary aerosol.

The ground-based aerosol number size distribution (Fig. 6) shows a huge Aitken mode for DNG profiles, while it is negligible for the other profile classes. This mode was characterized by a geometric mean diameter $D_{\mathrm{g}}$ of $0.032 \pm 0.001 \mu \mathrm{m}$ and by a geometric standard deviation $\sigma_{\mathrm{g}}$ of $1.790 \pm 0.006$ that were in agreement with 10-year average values reported in Tunved et al. (2013) at the Zeppelin observatory during the month of April. The presence of a clearly visible Aitken mode in DNG profiles supports the aforementioned hypothesis of the presence of a ground-based plume of locally and newly formed aerosol particles.

In order to estimate (meaning the order of magnitude) the contribution of locally formed aerosol, the method based on the $N /$ eBC ratio (Sect. 2.2.1), developed by Rodríguez and Cuevas (2007) was used. The value of $S_{1}(2.4 \pm 0.2)$ was taken as that of background aerosol above the ground $N_{14-260}$ plume in DNG profiles. This value was very similar to that measured during homogeneous profiles $(2.5 \pm 0.1)$ when a pure background aerosol was measured. These S1 values, obtained over Ny-Ålesund, are close to the lowest values reported in the literature (Reche et al., 2011; Dall'Osto et al., 2013), a fact resulting from the $d_{50}$ cutoff size of the miniDiSC ( $14 \mathrm{~nm}$; Sect. 2.2.1), which is higher than $d_{50}$ cutoff sizes $(\sim 2-7 \mathrm{~nm})$ usually present in the widely used condensation particle counters.

Using this reference $S_{1}$ value, $N_{1}$ (background number concentration) and $N_{2}$ (locally formed secondary aerosol) were computed as reported in Sect. 2.2.1. Their vertical behavior is reported in Fig. 9. The total amount of secondary aerosol close to the ground is clearly visible and accounted on average for $63.7 \pm 5.6 \%$ (up to $95 \%$ at ground) of the total $N_{14-260}$ plume. In fact, within these plumes, the $N_{14-260}$ / eBC ratio reached an average value of $22.5 \pm 5.4$ (maximum value of 54.8 at ground) clearly indicating the presence of a secondary formed aerosol (Reche et al., 2011; Dall'Osto et al., 2013). In addition to this, Fig. 10 shows the temporal behavior of SMPS plus APS data collected at Gruvebadet during April 2011 together with the percentiles (25, 50,75 and 90 th percentiles of the measured number size distribution. The presence of nanoparticles (below $100 \mathrm{~nm}$ ) is clearly evident, even in springtime in the Arctic. 


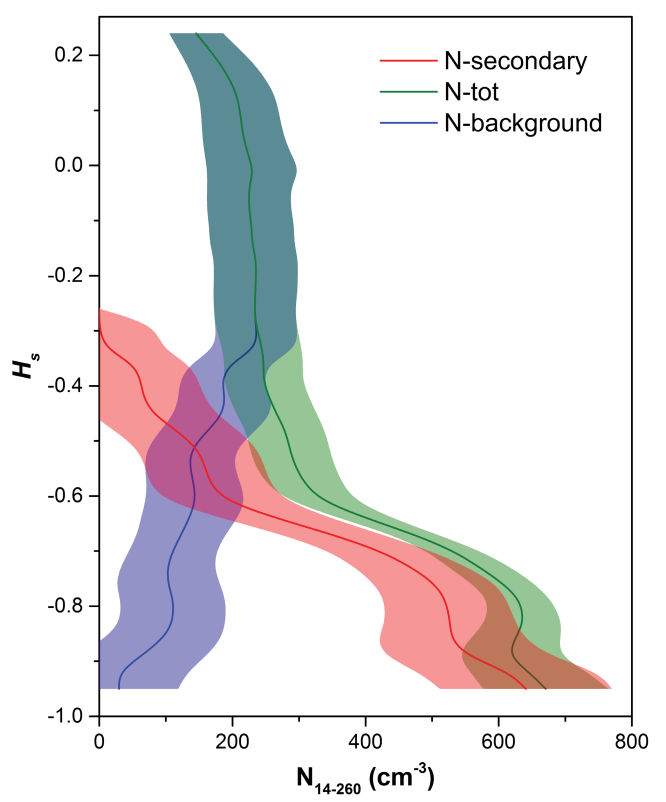

Figure 9. Springtime statistical mean profiles of $N_{14-260}$ (green line) apportioned along height for the contribution of background $N_{14-260}$ aerosol (blue line) and of secondary locally formed $N_{14-260}$ aerosol (red line) for the decoupled negative gradient profiles (DNG) category.

Interestingly, all the aforementioned results are analogous to data reported in ARCPAC by Brock et al. (2011). Within the surface inversion layer over sea ice, they found a region of depleted BC and organic mass concentrations (lower than in the background case), while sulfate concentrations were similar or higher. However, under this condition, Brock et al. (2011), did not feature an increase in particle number concentration. Surprisingly, DNG profiles are more similar to vertical aerosol profiles discussed by Kupiszewski et al. (2013) during the summertime ASCOS campaign. In fact, they found a plume of nanoparticles within the near-surface layer (not related to the behavior of accumulation-mode particles) during new particle formation events. They hypothesize that the origin of ultrafine particles was related to biological processes. This observation becomes important when considering again the number size distribution reported in Fig. 10. The 75 and 90th percentiles exhibited a summer-like behavior when compared with Zeppelin data reported in Engvall et al. (2008a) and in Tunved et al. (2013). These findings point towards the importance of measuring the frequencies of these episodes, present in the surface layer of Ny-Ålesund, together with their vertical development (i.e., vertical mixing), to understand their importance of CCN influencing the Arctic climate.

\subsection{Summer phenomenology}

Vertical profiles measured during summers 2011-2012 were also classified according to their vertical behavior (i.e., shape). They were averaged considering the relative position of each measured data point with respect to the $\mathrm{AS}_{\mathrm{h}}$. The obtained averaged vertical profiles were referred to the standardized height $H_{\mathrm{s}}$. The result of the classification and averaging procedure is reported in Fig. 11a-f (all profile data are reported in Fig. S8). In summer, two main categories were observed:

1. Type 1 , homogeneous profiles (HO), Fig. 11a-c and

2. Type 2, profiles characterized by the presence of shipping emissions (hereinafter referred to as SP), Fig. 11df.

Average concentrations of aerosol $\left(N_{14-260}, N_{260-1200}\right.$, $\left.N_{>1200}\right)$ and eBC below and above $H_{\mathrm{S}}=0$ for each profile class are summarized in Table 3.

\subsubsection{HO profiles}

HO profiles (Type 1; Fig. 11a-c) were observed in $37 \%$ of cases due to the summer higher solar power density at disposal together with the low albedo as discussed in Sect. 3.2. As already reported for springtime results, these are the only averaged profiles referred to an absolute height AGL because they did not show any $\mathrm{AS}_{\mathrm{h}}$ to calculate $H_{\mathrm{s}}$. During HO profiles, local wind (Fig. 5e) was interestingly blowing from the same direction as in the case of $\mathrm{HO}$ springtime profiles: SW direction, from the glaciers behind Ny-Ålesund (Fig. 1a) and not along the predominant NW-SE direction of the Kongsfjord. However, summertime HO profiles featured higher wind speed than in spring (range 0-11 $\mathrm{m} \mathrm{s}^{-1}$, average of $4.1 \pm 0.1 \mathrm{~m} \mathrm{~s}^{-1}$ at $33 \mathrm{~m}$; Table 2). At the same time, as shown in Fig. 11c, slightly positive $\theta$ profiles characterized, on average, the $\mathrm{HO}$ profiles.

The aerosol number concentrations were found to be $435.9 \pm 5.8 \mathrm{~cm}^{-3}$ for $N_{14-260}, 2.1 \pm 0.1 \mathrm{~cm}^{-3}$ for $N_{260-1200}$ and $4 \times 10^{-2} \pm 4 \times 10^{-3} \mathrm{~cm}^{-3}$ for $N_{>1200}$, respectively. Thus, $N_{14-260}$ accounted for $99.5 \pm 1.9 \%$ of the total aerosol number concentration, which is considerably higher than $81.9 \pm 16.8 \%$ observed in springtime HO profiles. This is in agreement with the observations reported in the literature that the sunlit summer period is dominated by small, locally formed Aitken particles (Giardi et al., 2016; Tunved et al., 2013; Ström et al., 2003, 2009; Udisti et al., 2013; Viola et al., 2013). eBC and the related $b_{\text {abs }}$ were negligible, as also reported by Eleftheriadis et al. (2009). HO profiles were observed in the absence of ships anchoring in the Ny-Ålesund harbor.

\subsubsection{Ship impact along vertical profiles}

Summer vertical profiles showed a considerable impact of ship emissions. The number of ships and the number of passengers (a useful proxy of the ship dimension) was registered by the Kings-Bay Kull Company and it is reported in Fig. S9 for summer 2011 and 2012, respectively. Particularly, 

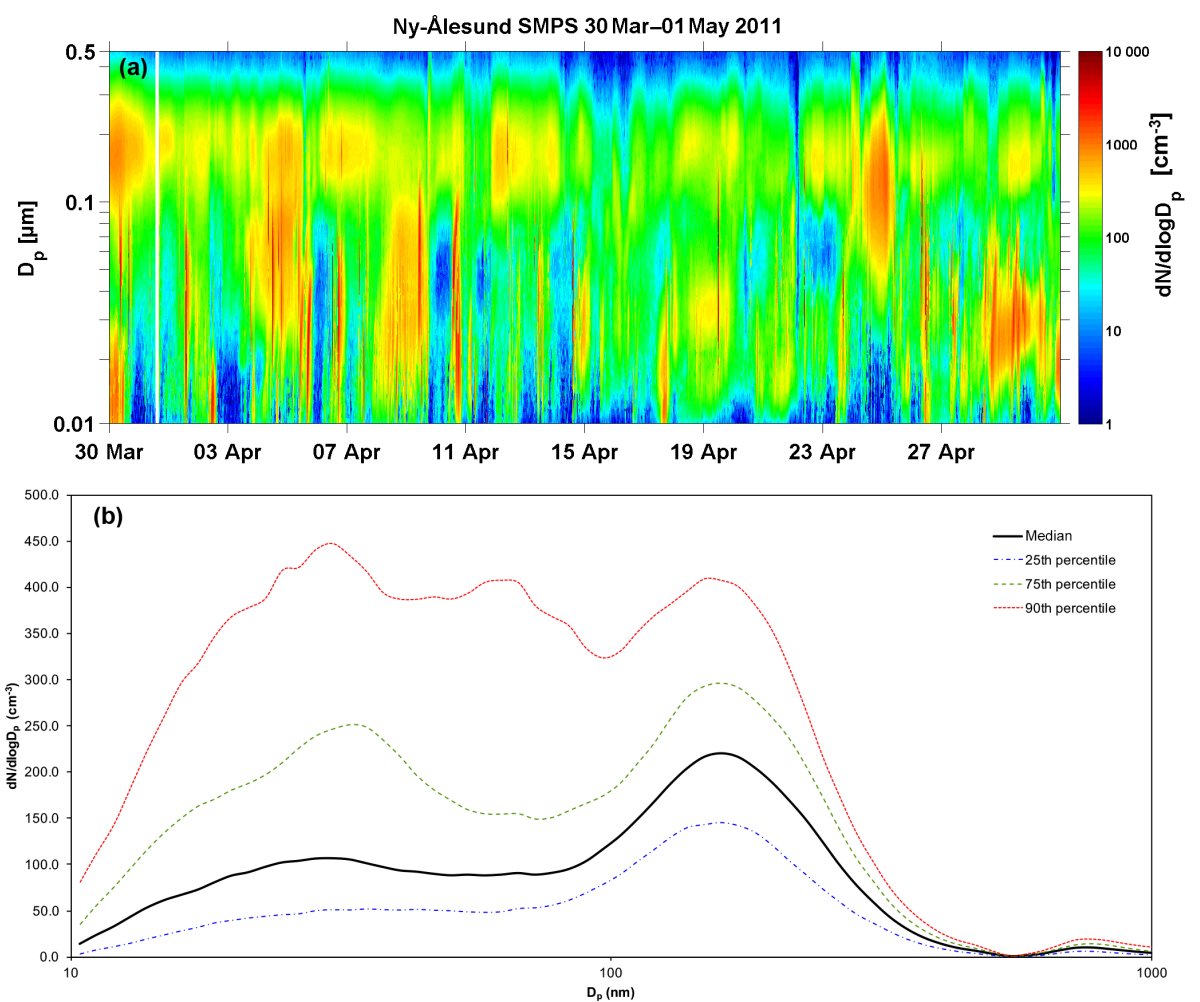

Figure 10. (a) Aerosol number size distribution measured at ground during April 2011; (b) 25, 50,75 and 90 th percentiles of the measured number size distribution.

57 days with a total of 103 ship arrivals were registered during JJA of 2011 (62\% of days; Fig. S9a) while 78 days (85\% of days) with 138 ships (Fig. S9b) were registered during JJA of 2012 .

Figure 12a-e report the case study of 6 July 2011, when four ships anchored (not simultaneously) in the harbor of $\mathrm{Ny}$ Ålesund from 07:00 to 19:00 UTC. The largest ship arrived in the morning with approx. 1000 passengers. Figure 12ad show four profiles (07:40, 09:01, 09:32 and 13:40 UTC) together with ground SMPS data collected at Gruvebadet (Fig. 12e). The ship impact in the Kongsfjord, distant by about $1200 \mathrm{~m}$, is clearly evident. $N_{14-260}$ concentrations reached values up to $2-3 \times 10^{4} \mathrm{~cm}^{-3}$ and the eBC concentrations reached the maximum value of $2000 \mathrm{ng} \mathrm{m}^{-3}$ (at 09:32 UTC).

To highlight the impact of ship emission along the 2 years, average vertical profiles were calculated. The result is shown in Fig. 11d-f. During SP, wind blew mainly from the NNE direction (where the harbor is located; Fig. 5f). The average wind speed was $2.6 \pm 0.1 \mathrm{~m} \mathrm{~s}^{-1}$. Once a ship plume arrived, SP profiles were characterized by high pollution levels below $H_{\mathrm{s}}=0$. Figure $11 \mathrm{f}$ also shows a positive gradient of $\theta\left(+1.4 \pm 0.2 \mathrm{~K}\right.$ increase from $\left.H_{\mathrm{s}}=0\right)$. This gradient constrains the ship plume above ground to an altitude variable with time as shown in Fig. 12a-d (from 103 to 592 m). Particularly, $N_{14-260}$ showed a concentration peak close to the ground of $9.0 \times 10^{3} \pm 2.5 \times 10^{2} \mathrm{~cm}^{-3}, N_{260-1200}$ of $7.0 \pm 0.7 \mathrm{~cm}^{-3}$ and $N_{>1200}$ of $6 \times 10^{-2} \pm 4 \times 10^{-3} \mathrm{~cm}^{-3}$. eBC concentrations behave similarly, reaching concentrations of $319 \pm 14 \mathrm{ng} \mathrm{m}^{-3}$. These concentration values were higher by a factor of $13.9 \pm 0.7\left(N_{14-260}\right), 5.1 \pm 0.5$ $\left(N_{260-1200}\right), 4.8 \pm 0.4\left(N_{>1200}\right)$ and $13.4 \pm 1.0(\mathrm{eBC})$ than those observed above $H_{\mathrm{S}}=0$ where an intense decrease of both aerosol and $\mathrm{eBC}$ is observed. Crossing the $\mathrm{AS}_{\mathrm{h}}$, aerosol concentrations decreased to $648.1 \pm 27.3 \mathrm{~cm}^{-3}$ for $N_{14-260}$, to $1.4 \pm 0.1 \mathrm{~cm}^{-3}$ for $N_{260-1200}$ and to $1 \times 10^{-2} \pm 1 \times 10^{-3} \mathrm{~cm}^{-3}$ for $N_{>1200}$. These values were close to the background values observed during summer $\mathrm{HO}$ profiles. eBC behave similarly, decreasing to $24 \pm 1 \mathrm{ng} \mathrm{m}^{-3}$. As the ship plume of $\mathrm{eBC}$ is located close to the ground, it may exert positive forcing (Flanner, 2013; Brock et al., 2011; Seinfeld and Pandis, 2006; Hansen and Nazarenko, 2004). In fact, the $b_{\text {abs }}$ reached values of $1.95 \pm 0.09 \mathrm{Mm}^{-1}$ below $H_{\mathrm{s}}=0$.

It is important to note that SP profiles were observed in summer. In summer (Browse et al., 2012; Quinn et al., 2008; Stohl et al., 2006) and the locally formed aerosol becomes dominant (Giardi et al., 2015; Tunved et al., 2013; Ström et al., 2003, 2009). Within this context, the SP profiles show that the rising shipping emissions in the Arctic (Corbett et al., 2010; Granier et al., 2006) could affect the concentrations and the vertical distribution of aerosol, resulting in a 

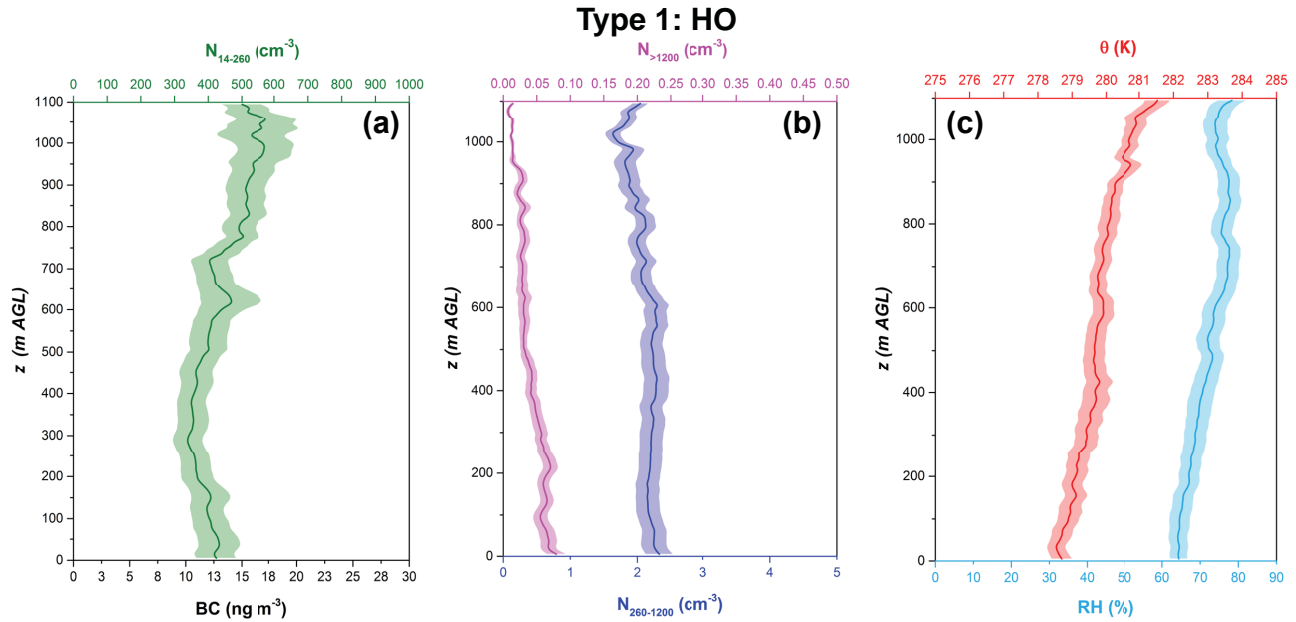

Type 2: SP
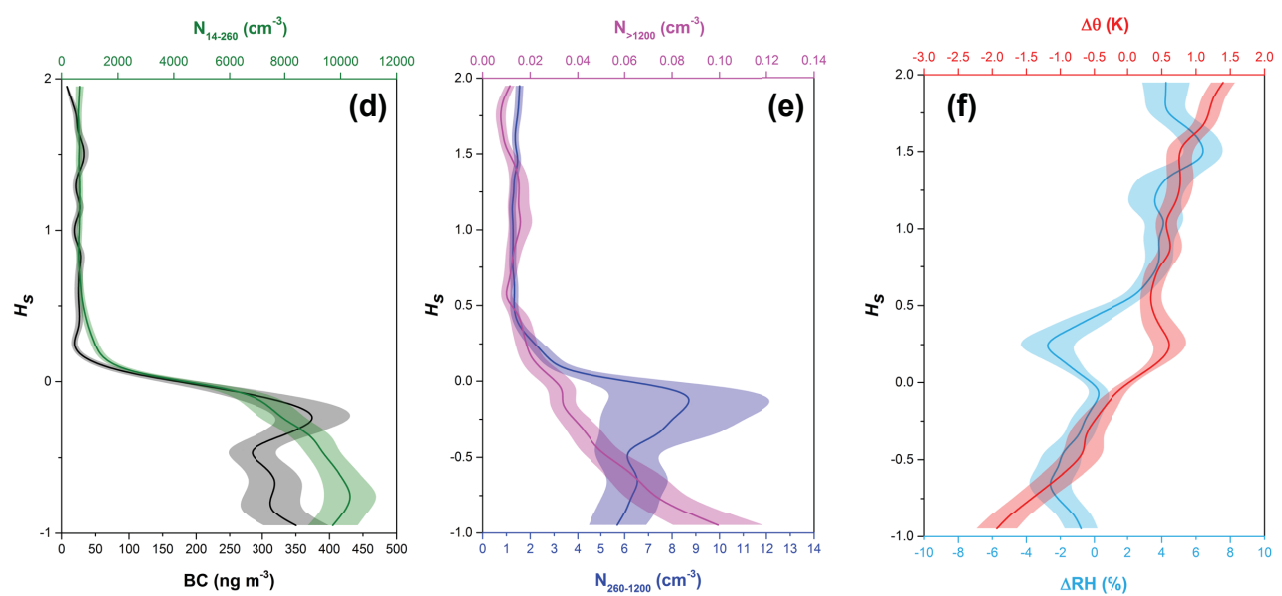

Figure 11. Summertime statistical mean profiles of $N_{14-260}$ (green line), BC (black line), $N_{260-1200}$ (blue line), $N_{>1200}$ (magenta line), $\theta$ (red line) and RH (light blue line) along height over Ny-Ålesund for the two typologies of vertical profiles: (a)-(c) homogeneous profiles (HO); (d)-(f) profiles impacted by shipping emissions (SP).

positive forcing, induced by a positive feedback through the local anthropogenic impact on climate.

\section{Conclusions}

Vertical profiles of in situ aerosol number size distribution and black carbon measurements were conducted by a tethered balloon in the atmosphere over Ny-Ålesund. The balloon payload was equipped with an optical particle counter (31 size classes, 0.25 to $32 \mu \mathrm{m}$ ), an electrical particle detector $\left(d_{50}=14 \mathrm{~nm}\right)$, two micro-aethalometers and meteorological sensors. Moreover, chemical analysis of filter samples, aerosol size distribution and a full set of meteorological parameters at ground were available. A systematic study of vertical profiles of aerosol number size distribution (14 nm$32 \mu \mathrm{m})$ and equivalent black carbon concentrations was conducted. A total of 200 vertical profiles were measured dur- ing spring and summer along 2 years (2011-2012). Vertical aerosol profiles were classified for each season according to their shape allowing to obtain a description of the seasonal phenomenology of vertical aerosol properties in the Arctic.

Focusing on spring, four main types of profiles were found.

The first one was the homogeneous profiles class (HO), characterized by constant aerosol and eBC concentration with altitude and representative of Arctic background conditions.

The second class was that of positive gradient profiles (PG), characterized by an increase of aerosol concentration with altitude. The importance of this class is related to the fact that aerosols can act as $\mathrm{CCN}$ influencing the cloud cover and thus the longwave fluxes.

The third class was characterized by negative gradient profiles (NG) with a decrease of aerosol concentration with al- 


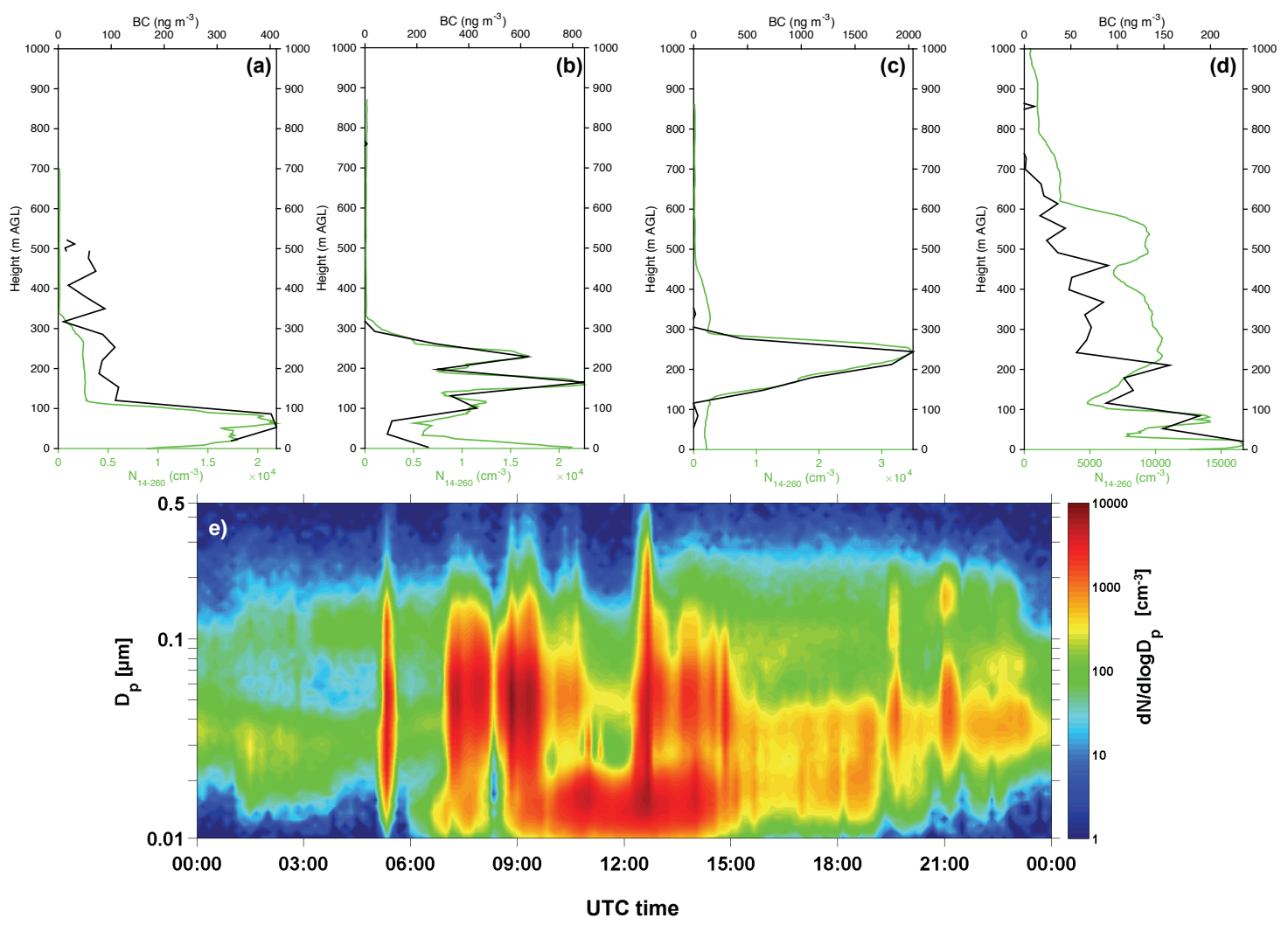

Figure 12. Case study of 6 July 2011 when four ships anchored (not simultaneously) in the harbor of Ny-Ålesund. Vertical profiles of $N_{14-260}$ (green line) and BC (black line) (07:40, 09:01, 09:32 and 13:40 UTC) are reported in panels from (a) to (d) together with ground SMPS data collected at Gruvebadet (e). Note the change in BC scale to progressively increasing BC values during the peak of the ship activity at midday.

titude and thus high pollution level close to the ground. This finding is very important because a $\mathrm{BC}$ layer located immediately above snow and ice may induce a positive forcing.

The fourth class of profiles was characterized by negative gradients located at different altitude as a function of size (DNG). These profiles were observed during ground-based events of locally formed secondary aerosol. It is important, as locally formed aerosol can act as CCN. As low clouds play a particular role in the sensitive Arctic climate system, the aerosol-cloud interactions will be one focus of future research activities within the Ny-Ålesund research community, manifested in the Ny-Ålesund atmospheric flagship program.

The four categories described above are important when considering the large amount of ground-based data available for comparisons with modeling results. Particularly, for HO profiles, ground measurements were fully representative of the vertical column (up until $\sim 1 \mathrm{~km}$, vertical limit of experimental activity). During NG and PG profiles, the groundbased measurements were representative of the air column up to the planetary boundary layer. Finally, DNG profiles showed that ground-based measurements differ from those conducted aloft. However, the last case was influenced by secondary aerosol formation that can be easily detected by an SMPS (or similar experimental devices). Thus, groundbased measurements (coupled with a proper PBL determination) are fundamental and very useful for model comparison. In addition to these, vertical profiles shed light on the phenomenology and dynamics of the vertical distribution of aerosols in the Arctic.

During summertime, two main types of profiles were observed. The first class was characterized by homogeneous background condition profiles, while the second class reflected the impact of shipping emissions. The ship impact resulted in a plume of aerosol and $\mathrm{eBC}$ pollution constrained close to the ground. In summer, atmospheric transport from midlatitudes is minor. Increasing shipping emissions in the Arctic could significantly increase anthropogenic aerosol and eBC concentrations in the Arctic summer, enhancing the climate change that this region is already experiencing.

\section{Data availability}

Data are available upon request. Requests specifically for vertical profiles can be made to the University of Milano-Bicocca and to University of Perugia 
(Luca Ferrero, luca.ferrero@unimib.it; David Cappelletti, david.cappelletti@unipg.it), for CCT data to CNR-ISAC (Mauro Mazzola, m.mazzola@isac.cnr.it). Raw data are also available at http://arcticnode.dta.cnr.it/cnr/). AWIPEV meteorological data are available at the PANGAEA database (doi:10.1594/PANGAEA.793046, Maturilli et al., 2013, and doi:10.1594/PANGAEA.809646, Maturilli, 2013). Requests for aerosol chemistry can be made to the University of Florence (Roberto Udisti, udisti@unifi.it).

\section{The Supplement related to this article is available online at doi:10.5194/acp-16-12601-2016-supplement.}

Acknowledgements. The scientific activity in Ny-Ålesund was carried out in the framework of the CNR Polar Program. We thank the PRIN2009 ARCTICA project for financial support. We thank the Alfred Wegener Institute and the CICCI project for logistical support. We thank both Brent Holben and Piotr Sobolewski for their effort in establishing and maintaining the AERONET Hornsund site. Finally, we thank LSI-Lastem and Federico Pasquini for the cooperation concerning meteorological instruments.

Edited by: K. Tsigaridis

Reviewed by: M. Sand and two anonymous referees

\section{References}

Andreae, M. O. and Gelencsér, A.: Black carbon or brown carbon? The nature of light-absorbing carbonaceous aerosols, Atmos. Chem. Phys., 6, 3131-3148, doi:10.5194/acp-6-3131-2006, 2006.

Arnott, W. P., Hamasha, K., Moosmüller, H., Sheridan, P. J., and Ogren, J. A.: Towards Aerosol Light-Absorption Measurements with a 7-Wavelength Aethalometer: Evaluation with a Photoacoustic Instrument and 3-Wavelength Nephelometer, Aerosol Sci. Tech., 39, 17-29, doi:10.1080/027868290901972, 2005.

Ban-Weiss, G. A., Cao, L., Bala, G., and Caldeira, K.: Dependence of climate forcing and response on the altitude of black carbon aerosols, Clim. Dynam., 38, 897-911, doi:10.1007/s00382-0111052-y, 2011.

Baron, P. A. and Willeke, K.: Aerosol measurements. Principles, Techniques and Applications, Wiley-Interscience, Second edition, ISBN-13: 978-0-471-78492-0, 2005.

Barrie, L. A. and Hoff, R. M: Five years of air chemistry observations in the Arctic, Atmos. Environ., 19, 1995-2010, 1985.

Bates, T. S., Quinn, P. K., Johnson, J. E., Corless, A., Brechtel, F. J., Stalin, S. E., Meinig, C., and Burkhart, J. F.: Measurements of atmospheric aerosol vertical distributions above Svalbard, Norway, using unmanned aerial systems (UAS), Atmos. Meas. Tech., 6, 2115-2120, doi:10.5194/amt-6-2115-2013, 2013.

Becagli, S., Ghedini, C., Peeters, S., Rottiers, A., Traversi, R., Udisti, R., Chiari, M., Jalba, A., Despiau, S., Dayan, U., and Temara, A.: MBAS (Methylene Blue Active Substances) and LAS (Linear
Alkylbenzene Sulphonates) in Mediterranean coastal aerosols: sources and transport processes, Atmos. Environ., 45, 67886801, 2011.

Becagli, S., Scarchilli, C., Traversi, R., Dayan, U., Severi, M., Frosini, D., Vitale, V., Mazzola, M., Lupi, A., Nava, S., and Udisti, R.: Study of present day sources and transport processes affecting oxidised sulphur compounds in atmospheric aerosols at Dome C (Antarctica) from year-round sampling campaigns, Atmos. Environ., 52, 98-108, 2012.

Bhatt, U. S., Walker, D. A., Raynolds, M. K., Comiso, J. C., Epstein, H. E., Gia, G.-S., Gens, R., Pinzon, J. E., Tucker, C. J., Tweediw, C. E., and Webber, P. J.: Circumpolar Arctic tundra vegetative change is linked to sea ice decline, Earth Interact., 14, 1-20, 2010.

Bond, T. C., Doherty, S. J., Fahey, D. W., Forster, P. M., Berntsen, T., Deangelo, B. J., Flanner, M. G., Ghan, S., Kärcher, B., Koch, D., Kinne, S., Kondo, Y., and Quinn, P. K.: Bounding the role of black carbon in the climate system?: A scientific assessment, J. Geophys. Res., 118, 1-173, doi:10.1002/jgrd.50171, 2013.

Bowen, H. J. M.: Environmental Chemistry of the Elements, Academic Press, London, ISBN-10: 0121204502, ISBN-13: 9780121204501, 1979.

Brock, C. A., Radke, L. F., Lyons, J. H., and Hobbs, P. V.: Arctic hazes in summer over Greenland and the North American Arctic, I, Incidence and origins, J. Atmos. Chem., 9, 129-148, 1989.

Brock, C. A., Cozic, J., Bahreini, R., Froyd, K. D., Middlebrook, A. M., McComiskey, A., Brioude, J., Cooper, O. R., Stohl, A., Aikin, K. C., de Gouw, J. A., Fahey, D. W., Ferrare, R. A., Gao, R.-S., Gore, W., Holloway, J. S., Hübler, G., Jefferson, A., Lack, D. A., Lance, S., Moore, R. H., Murphy, D. M., Nenes, A., Novelli, P. C., Nowak, J. B., Ogren, J. A., Peischl, J., Pierce, R. B., Pilewskie, P., Quinn, P. K., Ryerson, T. B., Schmidt, K. S., Schwarz, J. P., Sodemann, H., Spackman, J. R., Stark, H., Thomson, D. S., Thornberry, T., Veres, P., Watts, L. A., Warneke, C., and Wollny, A. G.: Characteristics, sources, and transport of aerosols measured in spring 2008 during the aerosol, radiation, and cloud processes affecting Arctic Climate (ARCPAC) Project, Atmos. Chem. Phys., 11, 2423-2453, doi:10.5194/acp-11-24232011, 2011.

Browse, J., Carslaw, K. S., Arnold, S. R., Pringle, K., and Boucher, O.: The scavenging processes controlling the seasonal cycle in Arctic sulphate and black carbon aerosol, Atmos. Chem. Phys., 12, 6775-6798, doi:10.5194/acp-12-6775-2012, 2012.

Browse, J., Carslaw, K. S., Schmidt, A., and Corbett, J. J.: Impact of future Arctic shipping on high-latitude black carbon deposition, Geophys. Res. Lett., 40, 4459-4463, doi:10.1002/grl.50876, 2013.

Corbett, J. J., Lack, D. A., Winebrake, J. J., Harder, S., Silberman, J. A., and Gold, M.: Arctic shipping emissions inventories and future scenarios, Atmos. Chem. Phys., 10, 9689-9704, doi:10.5194/acp-10-9689-2010, 2010.

Dai, C. Y., Gao, Z. Q., Wang, Q., and Cheng, G.: Analysis of atmospheric boundary layer height characteristics over the Arctic Ocean using the aircraft and GPS soundings, Atmos. Oceanic Sci. Lett., 4, 124-130, 2011.

Dall'Osto, M., Thorpe, A., Beddows, D. C. S., Harrison, R. M., Barlow, J. F., Dunbar, T., Williams, P. I., and Coe, H.: Remarkable dynamics of nanoparticles in the urban atmosphere, At- 
mos. Chem. Phys., 11, 6623-6637, doi:10.5194/acp-11-66232011, 2011.

Dall'Osto, M., Querol, X., Alastuey, A., O'Dowd, C., Harrison, R. M., Wenger, J., and Gómez-Moreno, F. J.: On the spatial distribution and evolution of ultrafine particles in Barcelona, Atmos. Chem. Phys., 13, 741-759, doi:10.5194/acp-13-741-2013, 2013.

Di Liberto, L., Angelini, F., Pietroni, I., Cairo, F., Di Donfrancesco, G., Viola, A., Argentini, S., Fierli, F., Gobbi, G., Maturilli, M., Neuber, R., and Snels, M.: Estimate of the Arctic Convective Boundary Layer Height from Lidar Observations: A Case Study, Adv. Met., 2012, 1-9, doi:10.1155/2012/851927, 2012.

Drinovec, L., Mocnik, G., Zotter, P., Prévôt, A. S. H., Ruckstuhl, C., Coz, E., Rupakheti, M., Sciare, J., Müller, T., Wiedensohler, A., and Hansen, A. D. A.: The "dual-spot" Aethalometer: an improved measurement of aerosol black carbon with realtime loading compensation, Atmos. Meas. Tech., 8, 1965-1979, doi:10.5194/amt-8-1965-2015, 2015.

Eckhardt, S., Stohl, A., Beirle, S., Spichtinger, N., James, P., Forster, C., Junker, C., Wagner, T., Platt, U., and Jennings, S. G.: The North Atlantic Oscillation controls air pollution transport to the Arctic, Atmos. Chem. Phys., 3, 1769-1778, doi:10.5194/acp-31769-2003, 2003.

Eckhardt, S., Hermansen, O., Grythe, H., Fiebig, M., Stebel, K., Cassiani, M., Baecklund, A., and Stohl, A.: The influence of cruise ship emissions on air pollution in Svalbard -a harbinger of a more polluted Arctic?, Atmos. Chem. Phys., 13, 8401-8409, doi:10.5194/acp-13-8401-2013, 2013.

Eleftheriadis, K., Vratolis, S., and Nyeki, S.: Aerosol black carbon in the European Arctic: Measurements at Zeppelin station, Ny-Ålesund, Svalbard from 1998-2007, Geophys. Res. Lett., 36, doi:10.1029/2008GL035741, 2009.

Engvall, A.-C., Krejci, R., Ström, J., Treffeisen, R., Scheele, R., Hermansen, O., and Paatero, J.: Changes in aerosol properties during spring-summer period in the Arctic troposphere, Atmos. Chem. Phys., 8, 445-462, doi:10.5194/acp-8-445-2008, 2008a.

Engvall, A.-C., Krejci, R., Ström, J., Minikin, A., Treffeisen, R., Stohl, A., and Herber, A.: In-situ airborne observations of the microphysical properties of the Arctic tropospheric aerosol during late spring and summer, Tellus B, 60B, 392-404, doi:10.1111/j.1600-0889.2008.00348.x, 2008b.

Ferrero, L., Bolzacchini, E., Petraccone S., Perrone, M. G., Sangiorgi, G., Lo Porto, C., Lazzati, Z., and Ferrini, B.: Vertical profiles of particulate matter over Milan during winter 2005/2006, Fresen. Envion. Bull., 16, 697-700, 2007.

Ferrero, L., Mocnik, G., Ferrini, B. S., Perrone, M. G., Sangiorgi, G., and Bolzacchini, E.: Vertical profiles of aerosol absorption coefficient from micro-Aethalometer data and Mie calculation over Milan, Sci. Total Environ., 409, 2824-2837, doi:10.1016/j.scitotenv.2011.04.022, 2011a.

Ferrero, L., Riccio, A., Perrone, M. G., Sangiorgi, G., Ferrini, B. S., and Bolzacchini, E.: Mixing height determination by tethered balloon-based particle soundings and modeling simulations, Atmos. Res., 102, 145-156, doi:10.1016/j.atmosres.2011.06.016, 2011 b.

Ferrero, L., Cappelletti, D., Moroni, B., Sangiorgi, G., Perrone, M. G., Crocchianti, S., and Bolzacchini, E.: Wintertime aerosol dynamics and chemical composition across the mixing layer over basin valleys, Atmos. Environ., 56, 143-153, doi:10.1016/j.atmosenv.2012.03.071, 2012.
Ferrero, L., Castelli, M., Ferrini, B. S., Moscatelli, M., Perrone, M. G., Sangiorgi, G., D’Angelo, L., Rovelli, G., Moroni, B., Scardazza, F., Mocnik, G., Bolzacchini, E., Petitta, M., and Cappelletti, D.: Impact of black carbon aerosol over Italian basin valleys: high-resolution measurements along vertical profiles, radiative forcing and heating rate, Atmos. Chem. Phys., 14, 96419664, doi:10.5194/acp-14-9641-2014, 2014.

Fierz, M., Houle, C., Steigmeier, P., and Burtscher, H.: Design, Calibration, and Field Performance of a Miniature Diffusion Size Classifier, Aerosol Sci. Tech., 45, 1-10, doi:10.1080/02786826.2010.516283, 2011.

Flanner, M. G.: Arctic climate sensitivity to local black carbon, J. Geophys. Res.-Atmos., 118, 1840-1851, doi:10.1002/jgrd.50176, 2013.

Francis, J. A. and Hunter, E.: New insight into the disappearing Arctic sea ice, EOS Trans. Am. Geophys. Union, 87, 509-511, 2006.

Giardi, F., Becagli, S., Traversi, R., Frosini, D., Severi, M., Caiazzo, L., Ancillotti, C., Cappelletti, D., Moroni, B., Grotti, M., Bazzano, A., Lupi, A., Mazzola, M., Vitale, V., Malandrino, M., Ferrero, L., Bolzacchini, E., Viola, A., and Udisti, R.: Size distribution and ion composition of aerosol collected at Ny Ålesund in the spring-summer field campaign 2013, Rend. Lincei, doi:10.1007/s12210-016-0529-3, 2016.

Gilardoni, S., Vignati, E., and Wilson, J.: Using measurements for evaluation of black carbon modeling, Atmos. Chem. Phys., 11, 439-455, doi:10.5194/acp-11-439-2011, 2011.

Granier, C., Niemeier, U., Jungclaus, J. H., Emmons, L., Hess, P., Lamarque, J.-F., Walters, S., and Brasseur, G. P.: Ozone pollution from future ship traffic in the Arctic northern passages, Geophys. Res. Lett., 33, L13807, doi:10.1029/2006GL026180, 2006.

Guyon, P., Boucher, O., Graham, B., Beck, J., Mayol-Bracero, O. L., Roberts, G. C., Maenhaut, W., Artaxo, P., and Andreae, M. O.: Refractive index of aerosol particles over the Amazon tropical forest during LBA-EUSTACH 1999, J. Aerosol Sci., 34, 883907, doi:10.1016/S0021-8502(03)00052-1, 2003.

Hansen, A. D. A. and Novakov, T.: Aerosol black carbon measurements in the Arctic haze during AGASP-II, J. Atmos. Chem., 9, 347-361, doi:10.1007/BF00052842, 1989.

Hansen, J. and Nazarenko, L.: Soot Climate Forcing via Snow and Ice Albedo, P. Natl. Acad. Sci. USA, 101, 423-428, doi:10.1073/pnas.2237157100, 2004.

Heim, M., Mullins, B. J., Umhauer, H., and Kasper, G.: Performance evaluation of three optical particle counters with an efficient "multimodal" calibration method, J. Aerosol Sci., 39, 1019-1031, doi:10.1016/j.jaerosci.2008.07.006, 2008.

Heyder, J. and Gebhart, J.: Optimization of response functions of light scattering instruments for size evaluation of aerosol particles, Appl. Optics, 18, 705-11, 1979.

Hoffmann, A., Ritter, C., Stock, M., Shiobara, M., Lampert, A., Maturilli, M., Orgis, T., Neuber, R., and Herber, A.: Ground-based lidar measurements from Ny-Ålesund during ASTAR 2007, Atmos. Chem. Phys., 9, 9059-9081, doi:10.5194/acp-9-9059-2009, 2009.

Howell, S. G., Clarke, A. D., Shinozuka, Y., Kapustin, V., McNaughton, C. S., and Huebert, B. J.: Influence of relative humidity upon pollution and dust during ACE-Asia: Size distributions and implications for optical properties, J. Geophys. Res., 111, D06205, doi:10.1029/2004JD005759, 2006. 
Intrieri, J. M., Fairall, C. W., Shupe, M. D., Persson, P. O. G., Andreas, E. L., Guest, P. S., and Moritz, R. E.: Annual cycle of Arctic surface cloud forcing at SHEBA, J. Geophys. Res., 107, C10, doi:10.1029/2000JC000439, 2002.

IPCC, 2013: Climate Change 2013: The Physical Science Basis, Cambridge University Press, Cambridge, United Kingdom and New York, USA, available at: http://www.ipcc.ch/report/ar5/ wg1/ (last access: October 2016), 2013.

Jacob, D. J., Crawford, J. H., Maring, H., Clarke, A. D., Dibb, J. E., Emmons, L. K., Ferrare, R. A., Hostetler, C. A., Russell, P. B., Singh, H. B., Thompson, A. M., Shaw, G. E., McCauley, E., Pederson, J. R., and Fisher, J. A.: The Arctic Research of the Composition of the Troposphere from Aircraft and Satellites (ARCTAS) mission: design, execution, and first results, Atmos. Chem. Phys., 10, 5191-5212, doi:10.5194/acp-10-5191-2010, 2010.

Jacobson, M. Z.: Short-term effects of controlling fossil-fuel soot, biofuel soot and gases, and methane on climate, arctic ice, and air pollution health, J. Geophys. Res., 115, D14209, doi:10.1029/2009JD013795, 2010.

Kaufman, Y. J., Tanré, D., and Boucher, O.: A satellite view of aerosols in the climate system, Nature, 419, 215-223, 2002.

Kirkby, J., Curtius, J., Almeida, J., Dunne, E., Duplissy, J., Ehrhart, S., Franchin, A., Gagné, S., Ickes, L., Kürten, A., Kupc, A., Metzger, A., Riccobono, F., Rondo, L., Schobesberger, S., Tsagkogeorgas, G., Wimmer, D., Amorim, A., Bianchi, F., Breitenlechner, M., David, A., Dommen, J., Downard, A., Ehn, M., Flagan, R. C., Haider, S., Hansel, A., Hauser, D., Jud, W., Junninen, H., Kreissl, F., Kvashin, A., Laaksonen, A., Lehtipalo, K., Lima, J., Lovejoy, E. R., Makhmutov, V., Mathot, S., Mikkilä, J., Minginette, P., Mogo, S., Nieminen, T., Onnela, A., Pereira, P., Petäjä, T., Schnitzhofer, R., Seinfeld, J. H., Sipilä, M., Stozhkov, Y., Stratmann, F., Tomé, A., Vanhanen, J., Viisanen, Y., Vrtala, A., Wagner, P. E., Walther, H., Weingartner, E., Wex, H., Winkler, P. M., Carslaw, K. S., Worsnop, D. R., Baltensperger, U., and Kulmala, M.: Role of sulphuric acid, ammonia and galactic cosmic rays in atmospheric aerosol nucleation., Nature, 476, 429-433, doi:10.1038/nature10343, 2011.

Koch, D., Schulz, M., Kinne, S., McNaughton, C., Spackman, J. R., Balkanski, Y., Bauer, S., Berntsen, T., Bond, T. C., Boucher, O., Chin, M., Clarke, A., De Luca, N., Dentener, F., Diehl, T., Dubovik, O., Easter, R., Fahey, D. W., Feichter, J., Fillmore, D., Freitag, S., Ghan, S., Ginoux, P., Gong, S., Horowitz, L., Iversen, T., Kirkevåg, A., Klimont, Z., Kondo, Y., Krol, M., Liu, X., Miller, R., Montanaro, V., Moteki, N., Myhre, G., Penner, J. E., Perlwitz, J., Pitari, G., Reddy, S., Sahu, L., Sakamoto, H., Schuster, G., Schwarz, J. P., Seland, Ø., Stier, P., Takegawa, N., Takemura, T., Textor, C., van Aardenne, J. A., and Zhao, Y.: Evaluation of black carbon estimations in global aerosol models, Atmos. Chem. Phys., 9, 9001-9026, doi:10.5194/acp-9-9001-2009, 2009.

Koren, I., Kaufman, Y. J., Remer, L. A., and Martins, J. V.: Measurments of the effect of amazon smoke on inhibition of cloud formation, Scienze, 303, 1342-1345, 2004.

Koren, I., Martins, J. V., Remer, L. A., and Afargan, H.: Smoke invigoration versus inhibition of clouds over the amazon, Science, 321, 946-949, 2008.

Kupiszewski, P., Leck, C., Tjernström, M., Sjogren, S., Sedlar, J., Graus, M., Müller, M., Brooks, B., Swietlicki, E., Norris, S., and Hansel, A.: Vertical profiling of aerosol particles and trace gases over the central Arctic Ocean during summer, Atmos. Chem. Phys., 13, 12405-12431, doi:10.5194/acp-13-12405-2013, 2013.

Lanconelli, C., Busetto, M., Mazzola, M., Lupi, A., Becagli, S., Frosini, D., Virkkula, A., and Vitale, V.: Physical, Chemical and Optical Properties of Aerosol at Ny Ålesund, 189 Svalbard: a Closure Study, Proceeding at the 1st Iberian Meeting on Aerosol Sci. Tech., 1-3 July 2013, ISBN-13: 978-989-20-3962-6, 189192, 2013.

Liu, Y. and Daum, P. H.: Relationship of refractive index to mass density and self-consistency of mixing rules for multicomponent mixtures like ambient aerosols, J. Aerosol Sci., 39, 974-986, doi:10.1016/j.jaerosci.2008.06.006, 2008.

Lovejoy, E. R.: Atmospheric ion-induced nucleation of sulfuric acid and water, J. Geophys. Res., 109, D08204, doi:10.1029/2003JD004460, 2004.

Ma, X., Lu, J. Q., Brock, R. S., Jacobs, K. M., Yang, P., and Hu, X.-H.: Determination of complex refractive index of polystyrene microspheres from 370 to $1610 \mathrm{~nm}$, Phys. Med. Biol., 48, 41654172, 2003.

Manabe, S. and Wetherald, R. T.: The effect of doubling the $\mathrm{CO}_{2}$ concentration on the climate of a general circulation model, J. Atmos. Sci., 32, 3-15, 1975.

Massabò, D., Caponi, L., Bernardoni, V., Bove, M. C., Brotto, P., Calzolai,, G., Cassola, F., Chiari, M., Fedi, M. E., Fermo, P., Giannoni, M., Lucarelli, F., Nava, S., Piazzalunga, A., Valli, G., Vecchi, R., and Prati, P.: Multi-wavelength optical determination of black and brown carbon in atmospheric aerosols, Atmos. Environ., 108, 1-12, 2015.

Maturilli, M.: Basic and other measurements of radiation at station Ny-Ålesund (2012-07), Alfred Wegener Institute - Research Unit Potsdam, available at: doi:10.1594/PANGAEA.809646, 2013.

Maturilli, M. and Kayser, M.: Arctic warming, moisture increase and circulation changes observed in the Ny-Ålesund homogenized radiosonde record, Theor. Appl. Climatol., 1-17 pp., doi:10.1007/s00704-016-1864-0, 2016.

Maturilli, M., Herber, A., König-Langlo, G.: Continuous meteorological observations at station Ny-Ålesund, 1993-08 to 201107, available at: doi:10.1594/PANGAEA.793046, Supplement to: Maturilli, M. et al.: Climatology and time series of surface meteorology in Ny-Ålesund, Svalbard, Earth Syst. Sci. Data, 5, 155-163, doi:10.5194/essd-5-155-2013, 2013.

Maturilli, M., Herber, A., and König-Langlo, G.: Basic and other measurements of radiation from the Baseline Surface Radiation Network (BSRN) Station Ny-Ålesund in the years 1992 to 2013, reference list of 253 datasets, doi:10.1594/PANGAEA.150000, Supplement to: Maturilli, M., Herber, A., and König-Langlo, G.: Surface radiation climatology for Ny-Ålesund, Svalbard $\left(78.9^{\circ} \mathrm{N}\right)$, basic observations for trend detection, Theor. Appl. Climatol., 120, 331-339, doi:10.1007/s00704-014-1173-4, 2014.

Mazzola, M., Viola, A. P., Lanconelli, C., and Vitale, V.: Atmospheric observations at the Amundsen-Nobile Climate Change Tower in Ny-Alesund, Svalbard. Rend. Lincei, 27, S7-S18, doi:10.1007/s12210-016-0514-x, 2016a.

Mazzola, M., Tampieri, F., Viola, A. P., Lanconelli, C., and Choi, T.: Stable boundary layer vertical scales in the Arctic: observations and analyses at Ny-Ålesund, Svalbard, Q. J. Roy. Meteor. Soc., 142, 1250-1258, 2016b. 
Moroni, B., Becagli, S., Bolzacchini, E., Busetto, M., Cappelletti, D., Crocchianti, S., Ferrero, L., Frosini, D., Lanconelli, C., Lupi, A., Maturilli, M., Mazzola, M., Perrone, G., Sangiorgi, G., Traversi, R., Udisti, R., Viola, A., and Vitale, V.: Sources and properties of aerosol particles upon Ny-Ålesund (Svalbard Islands): results of integrated vertical profile measurements and electron microscopy analyses, Advances in Meteorology, 2015, 1-11, 2015.

Nozaki, Y.: A Fresh Look at Element Distribution in the North Pacific, available at: http://www.aquamaris.org/wp-content/ uploads/Composición-AM-Tokyo.pdf (last access: October 2016), 1997.

Ødemark, K., Dalsøren, S. B., Samset, B. H., Berntsen, T. K., Fuglestvedt, J. S., and Myhre, G.: Short-lived climate forcers from current shipping and petroleum activities in the Arctic, Atmos. Chem. Phys., 12, 1979-1993, doi:10.5194/acp-12-1979-2012, 2012.

Overland, J. E. and Wang, M.: Large-scale atmospheric circulation changes are associated with the recent loss of Arctic sea ice, Tellus, 62A, 1-9, 2010.

Petzold, A., Ogren, J. A., Fiebig, M., Laj, P., Li, S.-M., Baltensperger, U., Holzer-Popp, T., Kinne, S., Pappalardo, G., Sugimoto, N., Wehrli, C., Wiedensohler, A., and Zhang, X.-Y.: Recommendations for reporting "black carbon" measurements, Atmos. Chem. Phys., 13, 8365-8379, doi:10.5194/acp-13-83652013, 2013.

Quinn, P. K., Miller, T. L., Bates, T. S., Ogren, J. A., Andrews, E., and Shaw, G. E.: A three-year record of simultaneously measured aerosol chemical and optical properties at Barrow, Alaska, J. Geophys. Res., 107, doi:10.1029/2001JD001248, 2002.

Quinn, P. K., Bates, T. S., Baum, E., Doubleday, N., Fiore, A. M., Flanner, M., Fridlind, A., Garrett, T. J., Koch, D., Menon, S., Shindell, D., Stohl, A., and Warren, S. G.: Short-lived pollutants in the Arctic: their climate impact and possible mitigation strategies, Atmos. Chem. Phys., 8, 1723-1735, doi:10.5194/acp8-1723-2008, 2008.

Radke, L. F., Lyons, J. H., Hegg, D. A., Hobbs, P. V., and Bailey, I. H.: Airborne observations of Arctic aerosols, I, Characteristics of Arctic haze, Geophys. Res. Lett., 11, 393-396, 1984.

Ramana, M. V, Ramanathan, V., Kim, D., Roberts, G. C., and Corrigan, C. E.: Albedo, atmospheric solar absorption and heating rate measurements with stacked UAVs, 1931, 1913-1931, doi:10.1002/qj.172, 2007

Ramanathan, V. and Feng, Y.: Air pollution, greenhouse gases and climate change: Global and regional perspectives, Atmos. Environ., 43, 37-50, doi:10.1016/j.atmosenv.2008.09.063, 2009.

Ran, L., Deng, Z., Xu, X., Yan, P., Lin, W., Wang, Y., Tian, P., Wang, P., Pan, W., and Lu, D.: Vertical profiles of black carbon measured by a micro-aethalometer in summer in the North China Plain, Atmos. Chem. Phys., 16, 10441-10454, doi:10.5194/acp16-10441-2016, 2016.

Reche, C., Querol, X., Alastuey, A., Viana, M., Pey, J., Moreno, T., Rodríguez, S., González, Y., Fernández-Camacho, R., de la Rosa, J., Dall'Osto, M., Prévôt, A. S. H., Hueglin, C., Harrison, R. M., and Quincey, P.: New considerations for PM, Black Carbon and particle number concentration for air quality monitoring across different European cities, Atmos. Chem. Phys., 11, 6207-6227, doi:10.5194/acp-11-6207-2011, 2011.
Reddington, C. L., Carslaw, K. S., Spracklen, D. V., Frontoso, M. G., Collins, L., Merikanto, J., Minikin, A., Hamburger, T., Coe, H., Kulmala, M., Aalto, P., Flentje, H., Plass-Dülmer, C., Birmili, W., Wiedensohler, A., Wehner, B., Tuch, T., Sonntag, A., O’Dowd, C. D., Jennings, S. G., Dupuy, R., Baltensperger, U., Weingartner, E., Hansson, H.-C., Tunved, P., Laj, P., Sellegri, K., Boulon, J., Putaud, J.-P., Gruening, C., Swietlicki, E., Roldin, P., Henzing, J. S., Moerman, M., Mihalopoulos, N., Kouvarakis, G., Ždímal, V., Zíková, N., Marinoni, A., Bonasoni, P., and Duchi, R.: Primary versus secondary contributions to particle number concentrations in the European boundary layer, Atmos. Chem. Phys., 11, 12007-12036, doi:10.5194/acp-11-12007-2011, 2011.

Riccobono, F., Schobesberger, S., Scott, C. E., Dommen, J., Ortega, I. K., Rondo, L., Almeida, J., Amorim, A., Bianchi, F., Breitenlechner, M., David, A., Downard, A., Dunne, E. M., Duplissy, J., Ehrhart, S., Flagan, R. C., Franchin, A., Hansel, A., Junninen, H., Kajos, M., Keskinen, H., Kupc, A., Kurten, A., Kvashin, A. N., Laaksonen, A., Lehtipalo, K., Makhmutov, V., Mathot, S., Nieminen, T., Onnela, A., Petaja, T., Praplan, A. P., Santos, F. D., Schallhart, S., Seinfeld, J. H., Sipila, M., Spracklen, D. V., Stozhkov, Y., Stratmann, F., Tome, A., Tsagkogeorgas, G., Vaattovaara, P., Viisanen, Y., Vrtala, A., Wagner, P. E., Weingartner, E., Wex, H., Wimmer, D., Carslaw, K. S., Curtius, J., Donahue, N. M., Kirkby, J., Kulmala, M., Worsnop, D. R., and Baltensperger, U.: (Suppl.) Oxidation Products of Biogenic Emissions Contribute to Nucleation of Atmospheric Particles, Science, 344, 717-721, doi:10.1126/science.1243527, 2014.

Rodriguez, S. and Cuevas, E.: The contributions of "minimum primary emissions" and "new particle formation enhancements" to the particle number concentration in urban air, J. Aerosol Sci., 38, 1207-1219, doi:10.1016/j.jaerosci.2007.09.001, 2007.

Samset, B. H., Myhre, G., Schulz, M., Balkanski, Y., Bauer, S., Berntsen, T. K., Bian, H., Bellouin, N., Diehl, T., Easter, R. C., Ghan, S. J., Iversen, T., Kinne, S., Kirkevåg, A., Lamarque, J.F., Lin, G., Liu, X., Penner, J. E., Seland, Ø., Skeie, R. B., Stier, P., Takemura, T., Tsigaridis, K., and Zhang, K.: Black carbon vertical profiles strongly affect its radiative forcing uncertainty, Atmos. Chem. Phys., 13, 2423-2434, doi:10.5194/acp-13-24232013, 2013.

Samset, B. H., Myhre, G., Herber, A., Kondo, Y., Li, S.-M., Moteki, N., Koike, M., Oshima, N., Schwarz, J. P., Balkanski, Y., Bauer, S. E., Bellouin, N., Berntsen, T. K., Bian, H., Chin, M., Diehl, T., Easter, R. C., Ghan, S. J., Iversen, T., Kirkevåg, A., Lamarque, J.-F., Lin, G., Liu, X., Penner, J. E., Schulz, M., Seland, Ø., Skeie, R. B., Stier, P., Takemura, T., Tsigaridis, K., and Zhang, K.: Modelled black carbon radiative forcing and atmospheric lifetime in AeroCom Phase II constrained by aircraft observations, Atmos. Chem. Phys., 14, 12465-12477, doi:10.5194/acp14-12465-2014, 2014.

Sangiorgi, G., Ferrero, L., Perrone, M. G., Bolzacchini, E., Duane, M., and Larsen, B. R.: Vertical distribution of hydrocarbons in the low troposphere below and above the mixing height?: Tethered balloon measurements in Milan, Italy, Environ. Pollut., 159, 3545-3552, doi:10.1016/j.envpol.2011.08.012, 2011.

Sand, M., Berntsen, T. K., Kay, J. E., Lamarque, J. F., Seland, Ø., and Kirkevåg, A.: The Arctic response to remote and local forcing of black carbon, Atmos. Chem. Phys., 13, 211-224, doi:10.5194/acp-13-211-2013, 2013. 
Schmid, O., Artaxo, P., Arnott, W. P., Chand, D., Gatti, L. V., Frank, G. P., Hoffer, A., Schnaiter, M., and Andreae, M. O.: Spectral light absorption by ambient aerosols influenced by biomass burning in the Amazon Basin. I: Comparison and field calibration of absorption measurement techniques, Atmos. Chem. Phys., 6, 3443-3462, doi:10.5194/acp-6-3443-2006, 2006.

Schumann, T.: On the use of a modified clean-room optical particle counter for atmosperic aerosols at high relative humidity, Atmos. Res., 25, 499-520, doi:10.1016/0169-8095(90)90035-B, 1990.

Schwarz, J. P., Spackman, J. R., Gao, R. S., Watts, L. A., Stier, P., Schulz, M., Davis, S. M., Wofsy, S. C., and Fahey, D. W.: Global-scale black carbon profiles observed in the remote atmosphere and compared to models, Geophys. Res. Lett., 37, L18812, doi:10.1029/2010GL044372, 2010.

Schwarz, J. P., Samset, B. H., Perring, A. E., Spackman, J. R., Gao, R. S., Stier, P., Schultz, M. G., Moore, F. L., Ray, E. A., and Fahey, D. W.: Global-scale seasonally resolved black carbon vertical profiles over the Pacific, Geophys. Res. Lett., 40, 5542-5547, 2013.

Screen, J. A. and Simmonds, I.: The central role of diminishing sea ice in recent Arctic temperature amplification, Nature, 464, 1334-1337, 2010a.

Screen, J. A. and Simmonds, I.: Increasing fall-winter energy loss from the Arctic Ocean and its role in Arctic temperature amplification, Geophys. Res. Lett., 37, L16707, doi:10.1029/2010GL044136, 2010b.

Seibert, P., Beyrich, F., Gryning, S., Jo, S., Rasmussen, A., and Tercier, P.: Review and intercomparison of operational methods for the determination of the mixing height, Atmos. Environ., 34, 1001-1027, doi:10.1016/S1352-2310(99)00349-0, 2000.

Seinfeld, J. H. and Pandis, S. N.: Atmospheric chemistry and physics, From air pollution to climate change, WileyInterscience edition, ISBN-10: 0-471-72018-6, 2006.

Serreze, M. C. and Barry, R. G.: Processes and impacts of Arctic amplification: A research synthesis, Global Planet. Change, 77, 85-96, doi:10.1016/j.gloplacha.2011.03.004, 2011.

Serreze, M. C., Barrett, A. P., Slater, A. G., Steele, M., Zhang, J., and Trenberth, K. E.: The large-scale energy budget of the Arctic, J. Geophys. Res., 112, D11122, doi:10.1029/2006JD008230, 2007.

Shaw, G. E: The Arctic haze phenomenon, BAMS, 2403-2413, 1995.

Shindell, D. and Faluvegi, G.: Climate response to regional radiative forcing during the twentieth century, Nat. Geosci., 2, 294-300, doi:10.1038/ngeo473, 2009.

Shindell, D., Kuylenstierna, J. C. I., Vignati, E., Van Dingenen, R., Amann, M., Klimont, Z., Anenberg, S. C., Muller, N., JanssensMaenhout, G., Raes, F., Schwartz, J., Faluvegi, G., Pozzoli, L., Kupiainen, K., Höglund-Isaksson, L., Emberson, L., Streets, D., Ramanathan, V., Hicks, K., Kim Oanh, N. T., Milly, G., Williams, M., Demkine, V., and Fowler, D.: Simultaneously mitigating near-term climate change and improving human health and food security, Science, 335, 183-189, doi:10.1126/science.1210026, 2012.

Spackman, J. R., Gao, R. S., Neff, W. D., Schwarz, J. P., Watts, L. A., Fahey, D. W., Holloway, J. S., Ryerson, T. B., Peischl, J., and Brock, C. A.: Aircraft observations of enhancement and depletion of black carbon mass in the springtime Arctic, Atmos. Chem. Phys., 10, 9667-9680, doi:10.5194/acp-10-9667-2010, 2010.
Stock, M., Ritter, C., Herber, A., von Hoyningen-Huene, W., Baibakov, K., Gräser, J., Orgis, T., Treffeisen, R., Zinoviev, N., Makshtas, A., and Dethloff, K.: Springtime Arctic aerosol: Smoke versus haze, a case study for March 2008, Atmos. Environ., 52, 48-55, doi:10.1016/j.atmosenv.2011.06.051, 2012.

Stohl, A.: Characteristics of atmospheric transport into the Arctic troposphere, J. Geophys. Res., 111, D11306, doi:10.1029/2005JD006888, 2006.

Stohl, A., Klimont, Z., Eckhardt, S., Kupiainen, K., Shevchenko, V. P., Kopeikin, V. M., and Novigatsky, A. N.: Black carbon in the Arctic: the underestimated role of gas flaring and residential combustion emissions, Atmos. Chem. Phys., 13, 8833-8855, doi:10.5194/acp-13-8833-2013, 2013.

Stone, R. S., Herber, A., Vitale, V., Mazzola, M., Lupi, A., Schnell, R. C., Dutton, E. G., Liu, P. S. K., Li, S. M., Dethloff, K., Lampert, A., Ritter, C., Stock, M., Neuber, R., and Maturilli, M.: A three-dimensional characterization of Arctic aerosols from airborne Sun photometer observations: PAMARCMIP, J. Geophys. Res.-Atmos., 115, D13203, doi:10.1029/2009jd013605, 2010.

Ström, J., Umegård, J., Tørseth, K., Tunved, P., Hansson, H.-C., Holmén, K., Wismann, V., Herber, A., and König-Langlo, G.: One year of particle size distribution and aerosol chemical composition measurements at the Zeppelin Station, Svalbard, March 2000-March 2001, Phys. Chem. Earth, Parts A/B/C, 28, 11811190, doi:10.1016/j.pce.2003.08.058, 2003.

Ström, J., Engvall, A.-C., Delbart, F., Krejci, R., and Treffeisen, R.: On small particles in the Arctic summer boundary layer: observations at two different heights near Ny-Ålesund, Svalbard, Tellus B, 61, 473-482, doi:10.1111/j.1600-0889.2008.00412.x, 2009.

Tunved, P., Ström, J., and Krejci, R.: Arctic aerosol life cycle: linking aerosol size distributions observed between 2000 and 2010 with air mass transport and precipitation at Zeppelin station, Ny-Ålesund, Svalbard, Atmos. Chem. Phys., 13, 3643-3660, doi:10.5194/acp-13-3643-2013, 2013.

Turpin, B. J. and Lim, H. J.: Species contributions to PM2.5 mass concentrations: revisiting common assumptions for estimating organic mass, Aerosol Sci. Technol., 35, 602-610, 2001.

Udisti, R., Becagli, S., Benassai, S., Castellano, E., Fattori, I., Innocenti, M., Migliori, A., and Traversi, R.: Atmosphere-snow interaction by a comparison between aerosol and uppermost snow layers composition at Dome C (East Antarctica), Ann. Glaciol., 39, 53-61, 2004.

Udisti, R., Dayan, U., Becagli, S., Busetto, M., Frosini, D., Legrand, M., Lucarelli, F., Preunkert, S., Severi, M., Traversi, R., and Vitale, V.: Sea-spray aerosol in central Antarctica. Present atmospheric behavior and implications for paleoclimatic reconstructions, Atmos. Environ., 52, 109-120, 2012.

Udisti, R., Becagli, S., Frosini, D., Ghedini, C., Rugi, F., Severi, M., Traversi, R., Zanini, R., Calzolai, G., Chiari, M., Lucarelli, F., Nava, S., Ardini F, Grotti M, Vione D, Malandrino M, Bolzacchini E, Ferrero, L., Perrone, M.G., Sangiorgi, G., Francesconi, S., Giannarelli, S., Cappelletti, D., Moroni, B., Ceccato, D., Mittner, P., and Sartori, P.: Activity and preliminary results from the 2011-2012 field seasons at Ny-Ålesund, DTA 14/2013, 5368, CNR Edizioni, ISSN: 2239-5172, 2013.

Udisti, R., Bazzano, A., Becagli, S., Bolzacchini, E., Caiazzo, L., Cappelletti, D., Ferrero, L., Frosini, D., Giardi, F., Grotti, M., Lupi, A., Malandrino, M., Mazzola, M., Moroni, B., Severi, M., Traversi, R., Viola, A., and Vitale, V.: Sulfate source apportion- 
ment in the Ny Ålesund (Svalbard Islands) Arctic aerosol, Rend. Lincei, 27, S85-S94, doi:10.1007/s12210-016-0517-7, 2016.

Vavrus, S., Waliser, D., Schweiger, A., and Francis, J. A.: Simulations of 20th and 21st century Arctic cloud amount in the global climate models assessed in the IPCC AR4, Clim. Dyn., 33, 10991115, doi:10.1007/s00382-008-0475-6, 2009.

Vihma, T., Kilpeläinen, T., Manninen, M., Sjöblom, A., Jakobson, E., Palo, T., Jaagus, J., and Maturilli, M.: Characteristics of temperature and humidity inversions and low-level jets over Svalbard fjords in spring, Adv. Met., 2011, ID486807, doi:10.1155/2011/486807, 2011.

Viola, A., Vitale, V., Petroni, I., Tampieri, F., Mazzola, M., Lanconelli, C., Busetto, M., Lupi, A., Di Liberto, L., Conidi, A., Ianniello, A., Salvatori, R., Esposito, G., Spataro, F., Udisti, R., Becagli, S., Frosini, D., Ghedini, C., Traversi, R., Cappelletti, D., Valt, M., and Turetta, C.: Atmospheric studies at "Dirigibile Italia”, DTA 14/2013, 35-52, CNR Edizioni, ISSN: 2239-5172, 2013.

Wagenbach, D., Preunkert, S., Schäfer, J., Jung, W., and Tomadin, L.: Northward transport of Saharan dust recorded in a deep alpine ice core, in: The Impact of Desert Dust Across the Mediterranean, edited by: Guerzoni, S. and Chester, R., Environmental Science and Technology Library, vol. 11, Springer, the Netherlands, 291-300, 1996.
Warneke, C., Froyd, K. D., Brioude, J., Bahreini, R., Brock, C. A., Cozic, J., De Gouw, J. A., Fahey, D. W., Ferrare, R., Holloway, J. S., Middlebrook, A. M., Miller, L., Montzka, S., Schwarz, J. P., Sodemann, H., Spackman, J. R., and Stohl, A.: An important contribution to springtime Arctic aerosol from biomass burning in Russia, Geophys. Res. Lett., 37, L01801, doi:10.1029/2009GL041816, 2010.

Weingartner, E., Saathoff, H., Schnaiter, M., Streit, N., Bitnar, B., and Baltensperger, U.: Absorption of light by soot particles: determination of the absorption coefficient by means of aethalometers, J. Aerosol Sci., 34, 1445-1463, doi:10.1016/S00218502(03)00359-8, 2003.

Wofsy, S. C., the HIPPO Science Team and Cooperating Modellers and Satellite Teams: HIAPER Pole-to-Pole Observations (HIPPO): fine grained, global-scale measurements of climatically important atmospheric gases and aerosols, Philos. T. R. Soc., 369, 2073-2086, 2011.

Yang, X.-Y., Fyfe, J. C., and Flato, G. M.: The role of poleward energy transport in Arctictemperature evolution, Geophys. Res. Lett., 37, L14803, doi:10.1029/2010GL042487, 2010.

Zangrando, R., Barbaro, E., Zennaro, P., Rossi, S., Kehrwald, N. M., Gabrieli, J., Barbante, C., and Gambaro, A.: Molecular markers of biomass burning in Arctic aerosols, Environ. Sci. Tech., 47, 8565-8574, doi:10.1021/es400125r, 2013. 